\title{
IMPLIKASI UNDANG-UNDANG NOMOR 23 TAHUN 2014 TERHADAP PENGEMBANGAN MINERAL DAN BATUBARA
}

\author{
Implications of Law Number 23 Year 2014 towards the Development of \\ Mineral and Coal
}

\author{
BAMBANG YUNIANTO \\ Puslitbang Teknologi Mineral dan Batubara \\ Jalan Jenderal Sudirman 623, Bandung 40211 \\ Telp. 022 6030483, Fax. 0226003373 \\ e-mail: yunianto@tekmira.esdm.go.id
}

\begin{abstract}
ABSTRAK
Pemberian otonomi daerah dalam perjalanan sejarah pemerintahan di Indonesia telah beberapa kali mengalami perubahan. Perubahan tersebut sangat dipengaruhi oleh situasi nasional, dan perkembangan di luar negeri dalam rangka mempercepat pemerataan kemakmuran masyarakat di Indonesia. Dilihat dari perubahan sistem otonomi daerah yang diberlakukan, perubahan yang sangat prinsip dan mendasar terjadi tahun 2004, saat diberlakukannya Undang-undang Nomor 32 Tahun 2004, dan tahun 2014 dengan berlakunya Undang-Undang Nomor 23 Tahun 2014. Perubahan sistem otonomi daerah tahun 2014 dipandang banyak menimbulkan persoalan, sebagian kabupaten/kota menganggap pemberlakuan Undang-undang Nomor 23 Tahun 2014 dilakukan tanpa ada persiapan yang matang, undang-undang terlalu rinci mengatur, dan peraturan pemerintah sebagai pedoman pelaksanaannya belum disiapkan sehingga susah dipedomani dalam pelaksanaan di lapangan. Kewenangan kabupaten/kota atas energi dan sumber daya mineral di bidang mineral dan batubara seluruhnya ditarik ke provinsi, sehingga praktis kabupaten/kota tidak bisa melakukan apapun, sementara provinsi belum siap melaksanakan amanat undang-undang tersebut. Implikasi pemberlakuan Undang-Undang Nomor 23 Tahun 2014 menuntut perubahan Undang-Undang Nomor 4 Tahun 2009 sesegera mungkin, terkait pelimpahan kewenangan dari kabupaten/kota ke tingkat provinsi. Selain itu, dalam masa transisi pelimpahan kewenangan tersebut, pihak provinsi dan kabupaten/kota segera menindaklanjuti Surat Edaran dari Kementerian Dalam Negeri dan Kementerian Energi dan Sumber Daya Mineral, sambil menunggu penyelesaian peraturan pemerintah sebagai peraturan pelaksanaan Undang-Undang Nomor 23 Tahun 2014.
\end{abstract}

Kata kunci: otonomi daerah, surat edaran, Undang-Undang Nomor 23 Tahun 2014, mineral dan batubara

\begin{abstract}
Granting of regional autonomy in the Indonesia government history has been amended several times. The changes were heavily influenced by national circumstances and developments abroad in order to accelerate equitable welfare of people in Indonesia. Judging from changes in the regional autonomy system in force, the changes are very fundamental principles and occurred in 2004, when the enactment of Law Number 32 Year 2004, and in 2014 with the enactment of Law Number 23 Year 2014. Changes in the system of regional autonomy in 2014 raise many questions by a number of regency/city considering the implementation of Law Number 23 Year 2014 that performed without any preparation, the laws are too detailed set, and government regulations as guidelines for their implementation have not been prepared well. The authority of regency/city on energy and mineral resources in the field of mineral and coal its called entirely to the provinces, so the regency/city practically cannot do anything, meanwhile the province is not ready to implement the mandate of the law. The enactment of Law Number 23 Year 2014 requires changes in Law Number 4 Year 2009 as soon as possible, related to delegation of authority from the regency/city to the provincial level. In this transition, the
\end{abstract}


provincial and regency/city should follow a circular from the Ministry of the Internal Affair and the Ministry of Energy and Mineral Resources in waiting the completion of government regulation as the implementing regulations of Law Number 23 Year 2014.

Keywords: autonomy, circulars, Law Number 23 Year 2014, mineral and coal

\section{PENDAHULUAN}

Pemberian otonomi seluas-luasnya kepada daerah diarahkan untuk mempercepat terwujudnya kesejahteraan masyarakat melalui peningkatan pelayanan, pemberdayaan, dan peran-serta masyarakat. Di samping itu melalui otonomi luas, dalam lingkungan strategis globalisasi, daerah diharapkan mampu meningkatkan daya saing dengan memperhatikan prinsip demokrasi, pemerataan, keadilan, keistimewaan, dan kekhususan serta potensi dan keanekaragaman daerah dalam sistem Negara Kesatuan Republik Indonesia.

Dalam perjalanan sejarah ketatanegaraan Indonesia, pemberian otonomi daerah ternyata mengalami perubahan dari waktu ke waktu. Hal ini tidak terlepas dari situasi dan kondisi internal di dalam negeri serta mengikuti perkembangan di luar negeri, dengan tetap mengedepankan perlunya percepatan kesejahteraan seluruh rakyat Indonesia (Manan dan Magnar, 1997).

Presiden sebagai pemegang kekuasaan pemerintahan dibantu oleh menteri dan setiap menteri bertanggung jawab atas urusan pemerintahan tertentu dalam pemerintahan. Sebagian urusan pemerintahan menjadi tanggung jawab menteri tersebut yang sesungguhnya diotonomikan ke daerah. Konsekuensi menteri sebagai pembantu Presiden adalah kewajiban menteri atas nama Presiden untuk melakukan pembinaan dan pengawasan, agar penyelenggaraan pemerintahan daerah berjalan sesuai dengan ketentuan peraturan perundang-undangan. Agar tercipta sinergi antara pemerintah pusat dan daerah, kementerian/lembaga pemerintah nonkementerian berkewajiban membuat norma, standar, prosedur, dan kriteria (NSPK) untuk dijadikan pedoman bagi daerah dalam menyelenggarakan urusan pemerintahan yang diserahkan ke daerah dan menjadi pedoman bagi kementerian/lembaga pemerintah nonkementerian untuk melakukan pembinaan dan pengawasan.

Sebagaimana diamanatkan oleh Undang-Undang Dasar 1945, terdapat urusan pemerintahan yang sepenuhnya menjadi kewenangan pemerintah pusat yang dikenal dengan istilah urusan pemerintahan absolut, selain ada urusan pemerintahan konkuren. Urusan pemerintahan konkuren terdiri atas urusan pemerintahan wajib dan urusan pemerintahan pilihan yang dibagi antara pemerintah pusat, daerah provinsi, dan daerah kabupaten/kota. Urusan pemerintahan wajib dibagi dalam urusan pemerintahan wajib yang terkait pelayanan dasar dan urusan pemerintahan wajib yang tidak terkait dengan pelayanan dasar. Untuk urusan pemerintahan wajib yang terkait pelayanan dasar ditentukan standar pelayanan minimal (SPM) untuk menjamin hak-hak konstitusional masyarakat. Pembagian urusan pemerintahan konkuren antara daerah provinsi dengan daerah kabupaten/kota, walaupun urusan pemerintahan sama, perbedaannya terlihat dari skala atau ruang lingkup urusan pemerintahan tersebut. Daerah provinsi dan daerah kabupaten/ kota mempunyai urusan pemerintahan masingmasing yang sifatnya tidak hierarki, namun tetap akan terdapat hubungan antara pemerintah pusat, daerah provinsi, dan daerah kabupaten/kota dalam pelaksanaannya dengan mengacu pada NSPK yang dibuat oleh pemerintah pusat.

Di samping urusan pemerintahan absolut dan urusan pemerintahan konkuren, undang-undang juga mengenal adanya urusan pemerintahan umum. Urusan pemerintahan umum menjadi kewenangan Presiden sebagai kepala pemerintahan untuk menjamin hubungan yang serasi berdasarkan suku, agama, ras, dan antargolongan sebagai pilar kehidupan berbangsa dan bernegara serta memfasilitasi kehidupan demokratis. Presiden dalam pelaksanaan urusan pemerintahan umum di daerah melimpahkan kepada gubernur sebagai kepala pemerintahan provinsi dan kepada bupati/wali kota sebagai kepala pemerintahan kabupaten/kota.

Mengingat kondisi geografis yang sangat luas, maka untuk efektivitas dan efisiensi, pembinaan dan pengawasan atas penyelenggaraan urusan pemerintahan yang menjadi kewenangan daerah kabupaten/ kota, Presiden melimpahkan kewenangannya kepada gubernur untuk bertindak atas nama pemerintah pusat melakukan pembinaan dan pengawasan kepada daerah kabupaten/kota agar melaksanakan 
otonominya dalam koridor NSPK yang ditetapkan oleh pemerintah pusat. Karena perannya sebagai wakil Pemerintah Pusat, maka hubungan gubernur dengan pemerintah daerah kabupaten/kota bersifat hierarkis (Amrullah, 2010).

Pemberlakuan Undang-Undang Nomor 23 Tahun 2014 (UU 23/2014) sebagai pengganti UndangUndang Nomor 32 Tahun 2004 (UU 32/2004), telah memicu permasalahan baru, karena selain pemerintah daerah kabupaten/kota merasa diperlakukan tidak adil, juga disebabkan UU 23/2014 dikeluarkan tanpa persiapan yang matang, sehingga menimbulkan kegaduhan di berbagai daerah. Khusus di bidang mineral dan batubara, sebagai salah satu subsektor energi dan sumber daya mineral, seluruh kewenangan kabupaten/kota ditarik ke tingkat provinsi sebagai perpanjangan pemerintah pusat di daerah.

Tujuan kajian ini adalah mengidentifikasi permasalahan terkait urusan pemerintahan di bidang mineral dan batubara, serta diperolehnya solusi atas permasalahan tersebut atas pemberlakuan UU 23/2014 dalam rangka pengembangan mineral dan batubara. Adapun sasaran kajian adalah tersusunnya usulan kebijakan dalam rangka penyusunan peraturan perundang-undangan yang baru di bidang mineral dan batubara.

\section{METODE}

Pendekatan metodologis kajian ini menggunakan keilmuan kebijakan. Sebagaimana diketahui, kebijakan yang ideal ditetapkan berdasarkan hasil penelitian dan pengembangan. Perkembangan kehidupan modern memungkinkan konsep penelitian dan kebijakan itu dipadukan untuk memecahkan persoalan-persoalan aktual kebijakan. Penelitian dan kebijakan kini telah menjelma sebagai field of study, kebijakan diartikan sebagai tindakantindakan yang dimaksudkan untuk memecahkan masalah publik. Hal ini sejalan dengan pemikiran Marjuki (2013) bahwa semua ilmu pengetahuan harus berdasarkan kebenaran ilmu filsafat, maka filsafat harus selalu relevan dengan kondisi kekinian dan kedisinian. Relevansi ini terdapat dalam kata wisdom (kebijaksanaan), karena kebijaksanaan merupakan ruh kehidupan manusia.

Pemecahan masalah publik oleh pembuat kebijakan dilakukan atas dasar rekomendasi yang dibuat oleh peneliti kebijakan sesuai hasil penelitiannya. Kebijakan tidak dipersepsi dari sudut pandang politik pemerintahan, melainkan kebijakan sebagai objek studi (Meha, 2010; Anderson, 1994). Kebijakan sebagai field of study lebih menekankan pada 'apa yang dikerjakan' daripada 'apa yang diusulkan atau dikehendaki'. Sejalan dengan Rahayu (2011) kebijakan yang dimaksud sebagai latar penelitian kebijakan adalah tindakan-tindakan untuk memecahkan masalah sosial. Pemecahan masalah sosial oleh pembuat kebijakan dalam hal ini dilakukan atas dasar rekomendasi yang dibuat oleh peneliti kebijakan berdasarkan hasil penelitiannya.

Penelitian kebijakan ini mengoperasionalkan hubungan variabel implikasi pemberlakuan UU 23/2014, perubahan UU 4/2009, dan variabelantara sebagai parameter adalah pelimpahan kewenangan bidang mineral dan batubara dari kabupaten/kota ke provinsi. Dalam suatu penelitian kebijakan, metode penelitian tidak perlu terlalu terpaku pada metodologi, selama rekomendasinya dapat benar-benar memberikan jalan keluar yang efektif, karena penelitian kebijakan adalah penelitian mencari jalan keluar dari masalah. Dengan demikian, para akademisi bisa lebih arif menentukan metodologi yang dipakai dengan relevansi terhadap masalah yang dihadapi. Seperti dalam studi kebijakan publik, penelitian kebijakan dimaksudkan untuk menelaah tindakan-tindakan yang dilakukan pemerintah, mengapa tindakan itu dilakukan, dengan cara dan mekanisme apa dilakukan, untuk kepentingan siapa, dan bagaimana hasil, akibat, dan dampaknya (Sitorus, 2009). Akhirnya, penelitian kebijakan bisa menghasilkan rekomendasi yang menjadi dasar bagi perumusan kebijakan, menunjang implementasi kebijakan, atau untuk mengetahui kinerja dan dampak dari kebijakan. Mengingat cakupan penelitian kebijakan ini sangat luas, maka untuk dapat menghasilkan rekomendasi yang berbasis pada data empiris, diperlukan berbagai metode penelitian.

Dalam kajian ini digunakan metode penelitian survei, karena wilayah yang menjadi sasaran kebijakan cukup luas nasional, dengan mengambil sampel empat provinsi (Jawa Barat, Jawa Timur, Kalimantan Selatan, dan Kepulauan Bangka Belitung) yang dianggap mampu mewakili wilayah nasional di bidang mineral dan batubara. Untuk menguatkan hasil analisis, digunakan juga analisis data sekunder dokumen, yang bersumber dari laporan hasil penelitian yang sudah ada, yang menurut Mulyatiningsih (2011) merupakan penggabungan dengan metode meta analisis. Dalam pengolahan dan analisis data digunakan teknik analogi deduktif dengan meng- 
operasionalkan teknik korelasional atas parameter variabel-variabel kajian melalui identifikasi tiap persoalan yang muncul agar ditemukan jawaban yang logik dan mendalam.

\section{DASAR HUKUM}

Dasar hukum otonomi daerah adalah Amandemen UUD 1945 Pasal 18, yang memuat paradigma baru dan arah politik pemerintahan daerah yang baru dalam menjalankan otonomi daerah, yaitu tentang prinsip daerah mengatur dan mengurus sendiri pemerintahannya menurut asas otonomi dan tugas pembantuan. Hal tersebut tertuang dalam UUD 1945 Pasal 18 ayat (2), yang menegaskan bahwa pemerintahan di daerah adalah pemerintahan otonomi dalam Negara Kesatuan Republik Indonesia (Siswoyo, 2014, Yendra, 2011). Selain itu, UUD 1945 Pasal 18 Ayat 2 memuat prinsip menjalankan otonomi seluas-luasnya, kecuali urusan pemerintahan yang oleh undang-undang ditentukan sebagai urusan pemerintahan pusat. Bidang yang tetap menjadi wewenang pemerintah pusat adalah politik luar negeri, pertahanan, keamanan, agama, yustisi, moneter, dan fiskal nasional.

\section{Otonomi Daerah di Awal Kemerdekaan sampai dengan Era Reformasi}

Rumusan prinsip atau asas otonomi sudah tertuang sejak awal kemerdekaan menyusul keluarnya UU $1 / 1945$, yang menyatakan adanya kemerdekaan pengaturan rumah tangga daerah asal selama bertentangan dengan pengaturan pemerintah pusat dan pemerintah daerah yang lebih luas daripadanya. Kemudian UU 22/1948, UU 1/1957, yang pada intinya memuat aturan hak pengaturan dan pengurusan rumah tangga sendiri berdasarkan hak otonomi dan medebewind, dan tidak berat ekonomi pada desa atau kota kecil.

Pada masa pemerintahan Orde Baru, dikeluarkan UU 18/1965, yang kemudian diganti oleh UU 5/1974, dan diubah lagi dengan UU 5/1979. Inti ketiga undang-undang ini adalah mengatur otonomi yang nyata dan bertanggung jawab, serta otonomi adalah hak, wewenang, dan sekaligus kewajiban. Pada era reformasi, paling tidak, sampai saat ini telah terjadi tiga kali perubahan undang-undang tentang otonomi daerah, yaitu dimulai dengan UU 22/1999 sebagai perubahan dari UU 5/1979, UU 32/2004, dan terakhir UU 23/2014. Perubahan mendasar terjadi saat UU 5/1979 diganti oleh UU 32/2004, dan saat UU 32/2014 diganti oleh UU 23/2014.
Pemberlakuan UU 22/1999 kurang berdampak bagi daerah (provinsi dan kabupaten/kota), karena otonomi daerah belum dilakukan secara utuh dan menyeluruh. Hal ini berbeda ketika UU 32/2004, yang memberikan otonomi seluas-luasnya kepada pemerintah kabupaten/kota untuk mengatur urusan rumah tangganya sendiri. Namun setelah berlangsung selama 10 tahun, undang-undang otonomi daerah kembali diganti oleh UU 23/2014, yang menitikberatkan otonomi daerah berada pada pemerintah daerah provinsi. Perubahan ini telah memicu permasalahan baru karena, selain pemerintah daerah kabupaten/kota merasa diperlakukan tidak adil, juga disebabkan UU 23/2014 dikeluarkan tanpa persiapan yang matang, sehingga menimbulkan kegaduhan di berbagai daerah (Muslimin dan Putra, 2015). Namun, tanpa perubahan, otonomi daerah di tingkat kabupaten/kota tersebut telah menimbulkan persoalan krusial yang perlu diredam (Ali dan Kalla, 2011). Persoalan tersebut meliputi: pertama, pemekaran daerah yang "kebablasan", seperti dalam tempo 10 tahun (1999-2009) lahir 205 daerah otonom baru; kedua, dalam hal kewenangan, tumpang-tindih, dan ketidakjelasan, termasuk ketidakseimbangan beban urusan antara provinsi dan kabupaten/kota ditata ulang; ketiga, jalinan hierarki pusat dan daerah yang selama ini putus di tingkat kabupaten/kota sehingga menimbulkan ketidakpatuhan bupati/wali kota kepada gubernur-dapat disambung kembali; dan keempat, kontrol pemerintah pusat yang sangat lemah terhadap kepala daerah diperkuat dengan sanksi-sanksi (Djohan, 2015).

Pelimpahan kewenangan bidang mineral dan batubara dari kabupaten/kota ke provinsi tersebut dapat dilacak berdasarkan hasil laporan Indonesia Governance Index 2014 (Malik, 2014) bahwa dalam era desentralisasi, kebijakan pusat sangat berpengaruh terhadap kapasitas daerah (Peters, 2011). Dari sekian isu yang sangat krusial dan harus segera dievaluasi, salah satu di antaranya adalah regulasi di bidang pertambangan. Di samping itu, adanya temuan Kementerian Dalam Negeri bahwa terdapat 369 peraturan daerah (perda) yang bermasalah sejak otonomi daerah di tingkat kabupaten/kota perlu mendapat perhatian (Sahlan, 2011). Persoalan ini sudah dimulai sejak diberlakukannya UU 22/1999 yang memberi wewenang kepada daerah untuk mengelola sumber daya yang berada di wilayahnya dan bertanggungjawab memelihara kelestarian lingkungan hidupnya sesuai dengan undang-undang. Tidak kurang dari 3.000 perda telah disusun oleh 324 kabupatan/kota dan 30 provinsi, sehingga menciptakan birokrasi perizinan yang panjang (Priyanto, 
2001). Idealnya, keberadaan perda berbanding lurus dari sisi kuantitas dan kualitas. Namun, realitanya saat ini tidak sedikit perda yang kualitasnya masih sangat jauh untuk dapat dikatakan baik atau sering diistilahkan dengan "perda bermasalah". Perda dikatakan bermasalah manakala pertama, perda bertentangan dengan peraturan yang lebih tinggi dan/atau bertentangan dengan kepentingan umum; kedua, dalam pelaksanaannya tidak berlaku efektif di tengah masyarakat; ketiga, mendapatkan penolakan dari masyarakat, baik karena dianggap tidak berpihak kepada masyarakat; keempat, perda tidak mendukung upaya menciptakan iklim usaha dan investasi yang kondusif di daerah (Yarni, 2014).

\section{Surat Edaran Kementerian Energi dan Sumber Daya Mineral dan Kementerian Dalam Negeri}

Dalam rangka menjamin kepastian hukum dan sambil menunggu terbitnya peraturan pelaksanaan UU 23/2014, maka pada masa transisi ini (dihitung selama dua tahun sejak UU 23/2014 diundangkan) pemerintah cq Kementerian Energi dan Sumber Daya Mineral dan Kementerian Dalam Negeri masing-masing telah mengeluarkan surat edaran untuk dipedomani oleh daerah.

\section{A. Kementerian Energi dan Sumber Daya Mineral}

Sehubungan dengan telah diterbitkannya UU 23/2014, maka Direktur Jenderal Mineral dan Batubara telah mengirim surat kepada Menteri Energi dan Sumber Daya Mineral Nomor 2066/06/ DJB/2014, yang pada intinya meminta agar menerbitkan Surat Edaran untuk mengisi kekosongan hukum pada masa transisi. Selanjutnya, Sekretaris Jenderal Kementerian Energi dan Sumber Daya Mineral juga telah membuat surat dengan Nomor 2115/30/SDB/2014 perihal Kewenangan Pengelolaan Pertambangan Mineral dan Batubara. Surat tersebut menyebutkan bahwa Kementerian Energi dan Sumber Daya Mineral akan menerbitkan produk hukum untuk mengatur masa transisi terkait perizinan pertambangan mineral dan batubara, yaitu terkait dengan permohonan, antara lain menyangkut permasalahan Izin Usaha Pertambangan (IUP), penerbitan Izin Pertambangan Rakyat (IPR) dalam Wilayah Pertambangan Rakyat (WPR) termasuk perpanjangan IPR; dan perubahan IUP Eksplorasi mineral logam atau batubara yang diajukan kepada Bupati/Walikota oleh pemohon WIUP/IUP/IPR dan pemegang IUP/IPR sebelum tanggal 2 Oktber 2014 dan telah diproses oleh dinas teknis daerah kabupaten/kota, maka dapat ditandatangani oleh
Bupati/Walikota setelah tanggal 2 Oktober 2014 sesuai UU 23/2014.

Pada 30 April 2015 Menteri Energi dan Sumber Daya Mineral mengeluarkan Surat Edaran Nomor 04.E/30/DJB/2015 tentang Penyelenggaraan Urusan Pemerintahan di Bidang Pertambangan Mineral dan Batubara. Butir-butir Surat Edaran ini adalah:

1) Bupati/walikota tidak lagi berwenang menyelenggarakan urusan pemerintahan di bidang pertambangan mineral dan batubara terhitung sejak tanggal 2 Oktober 2014.

2) Pasal-pasal dalam UU 4/2009 tentang Pertambangan Mineral dan Batubara beserta peraturan pelaksananya yang mengatur kewenangan bupati/walikota tidak mempunyai kekuatan hukum mengikat.

3) Untuk memberikan kepastian hukum dan kepastian berusaha kepada pemegang IUP mineral dan batubara, gubernur dan bupati/ walikota segera melakukan koordinasi terkait dengan penyerahan dokumen IUP mineral dan batubara dalam rangka penanaman modal dalam negeri (PMDN) yang telah dikeluarkan oleh bupati/walikota sebelum berlakunya UU 23/2014.

4) Dalam rangka pelaksanaan peralihan kewenangan penyelenggaraan urusan pemerintahan di bidang pertambangan mineral dan batubara, diminta kepada bupati/walikota untuk segera menyerahkan seluruh berkas perizinan kepada gubernur.

5) Dalam rangka pelaksanaan kewenangan pemerintah daerah provinsi di bidang pertambangan mineral dan batubara sebagaimana dimaksud dalam UU 23/2014, diminta kepada gubernur untuk segera memroses segala sesuatu yang menjadi kewenangannya.

6) Gubernur mengevaluasi berkas perizinan yang disampaikan oleh bupati/walikota.

\section{B. Kementerian Dalam Negeri}

Pada 16 Januari 2015, Menteri Dalam Negeri mengeluarkan Surat Edaran Nomor 120/253/Sj tentang Penyelenggaraan Urusan Pemerintahan Setelah Ditetapkan UU 23/2014. Pokok-pokok Surat Edaran ini adalah:

1) Penyelenggaraan urusan pemerintahan konkuren yang bersifat pelayanan kepada masyarakat luas dan masif, yang pelaksanaannya tidak dapat ditunda dan tidak dapat dilaksanakan tanpa dukungan personel, pendanaan, sarana dan prasarana, serta dokumen (P3D), tetap dilaksanakan oleh tingkatan/susunan 
pemerintahan yang saat ini menyelenggarakan urusan pemerintahan konkuren tersebut sampai dengan diserahkannya P3D (Catatan: ada 11 sub urusan yang termasuk ke dalam butir ini, tetapi sub-urusan bidang energi dan sumber daya mineral tidak termasuk di dalamnya).

2) Penyelenggaraan perizinan dalam bentuk pemberian atau pencabutan izin dilaksanakan oleh susunan/tingkatan pemerintahan sesuai dengan pembagian urusan pemerintahan konkuren sebagaimana dimaksud dalam UU 23/2014.

3) Penataan/perubahan perangkat daerah untuk melaksanakan urusan pemerintahan konkuren hanya dapat dilakukan setelah ditetapkannya hasil pemetaan urusan pemerintahan sebagaimana dimaksud dalam UU 23/2014.

4) Urusan pemerintahan umum sebagaimana dimaksud dalam Pasal 25 UU 23/2014 dilaksanakan oleh Badan/Kantor Kesbangpol dan/atau Biro/Bagian pada sekretariat daerah yang membidangi pemerintahan sebelum terbentuknya instansi vertikal yang membantu gubernur dan bupati/ walikota.

5) Pelaksanaan tugas dan wewenang gubernur sebagai wakil pemerintah pusat sebagaimana dimaksud dalam Pasal 91 UU 23/2014 dibantu oleh Satuan Kerja Perangkat Daerah (SKPD) provinsi sampai dengan dibentuknya perangkat gubernur sebagai wakil pemerintah pusat.

6) Diminta kepada gubernur, bupati, dan walikota untuk:

a) menyelesaikan secara seksama inventarisasi P3D antartingkatan/susunan pemerintahan sebagai akibat pengalihan urusan pemerintahan konkuren paling lambat tanggal 31 Maret 2016 dan serah terima P3D paling lambat tanggal 2 Oktober 2016.

b) gubernur, bupati/walikota segera berkoordinasi terkait dengan pengalihan urusan pemerintahan konkuren.

c) melakukan koordinasi dengan kementerian/lembaga terkait yang difasilitasi oleh Kementerian Dalam Negeri.

d) melakukan koordinasi dengan pimpinan DPRD masing-masing; dan

e) melaporkan pelaksanaan Surat Edaran ini kepada Menteri Dalam Negeri.

\section{Surat Edaran Gubernur}

Untuk menghadapi kekosongan peraturan, beberapa gubernur telah membuat surat edaran sebagai langkah antisipasi.
A. Surat Edaran Gubernur Kepulauan Bangka Belitung Nomor 540/241/DPE/2015 perihal Pembinaan dan Pengawasan Bidang Energi dan Sumber Daya Mineral

Surat Edaran ini memuat hal-hal sebagai berikut:

1) Bahwa pada saat UU 23/2014 mulai berlaku, semua peraturan perundangundangan yang berkaitan secara langsung dengan daerah wajib mendasarkan dan menyesuaikan dalam pengaturannya.

2) Sesuai dalam matriks pembagian urusan pemerintahan konkuren antara pemerintah pusat dan daerah provinsi dan daerah kabupaten/kota bidang energi dan sumber daya mineral, dalam rangka pembinaan dan pengawasan yang merupakan kewenangan daerah provinsi untuk menjadi perhatian dan berlaku sejak diterbitkan.

Berkenaan dengan hal di atas, maka bupati/ walikota tidak memberikan segala bentuk penetapan, penerbitan, dan persetujuan yang terkait dengan bidang energi dan sumber daya mineral dalam daerah provinsi.

B. Surat Edaran Gubernur Jawa Timur No. 545/1541/119.2/2014 tentang Tindak Lanjut Undang-undang Nomor 23 Tahun 2014 tentang Pemerintahan Daerah.

Untuk mengimplementasikan UU 23/2014, Pemerintah Daerah Provinsi Jawa Timur dalam konsolidasi perizinan pertambangan telah menerbitkan:

1) Peraturan Gubernur Jawa Timur Nomor 16 Tahun 2015 tentang Pedoman Pemberian Izin di Bidang ESDM sebagai Implementasi UU 23/2014.

2) Pengumpulan berkas IUP yang telah diterbitkan oleh kabupaten/kota.

3) Mengintruksikan kepada seluruh bupati/ walikota agar menghentikan Penerbitan Izin Usaha Pertambangan.

4) Mengintruksikan kepada seluruh bupati/ walikota agar menyerahkan data dan dokumen perizinan yang telah dikeluarkan dalam rangka pembinaan dan pengawasan terhadap pemegang izin.

5) Seluruh kabupaten/kota penghasil sumber daya alam pertambangan umum, tetap mendapatkan Dana Bagi Hasil, Pajak Daerah, dan Pajak Air Tanah. 
C. Surat Edaran Gubernur Jawa Barat Nomor 503/24/Investasi dan BUMD perihal Penyelenggaraan Perijinan di Jawa Barat, setelah ditetapkan Undang-undang Nomor 23 Tahun 2014 tentang Pemerintahan Daerah

Pemerintah Daerah Provinsi Jawa Barat tetap menjamin penyelenggaraan pelayanan publik yang optimal, dengan menerbitkan:

1) Peraturan Gubernur Jawa Barat Nomor 86 Tahun 2014 tentang Kebijakan Transisional Pelaksanaan UU 23/2014, dan Peraturan Gubernur Jawa Barat No.92/2014 tentang Penyelenggaraan Pelayanan Perizinan Terpadu.

2) Instruksi Gubernur Jawa Barat No.4/2014 tentang Pelaksanaan Urusan Pemerintahan Konkuren Berdasarkan UU 23/2014.

3) Kesepakatan Bersama antara Pemerintahan Provinsi Jawa Barat dengan pemerintah kabupaten/kota se Jawa Barat Nomor 119/83/Otda/ Ksm tanggal 23 Desember 2014, tentang Penyelenggaraan Urusan Pemerintahan Daerah Dalam Pelayanan Publik setelah ditetapkannya UU 23/2014.

Pemerintah Provinsi Jawa Barat masih membutuhkan bantuan pemerintah kabupaten/kota dalam rangka optimalnya pelayanan perizinan, di antaranya:

1) Perizinan yang telah diterbitkan oleh pemerintah kabupaten/kota pascaberlakunya UU 23/2014, dan sebelum terbitnya Peraturan Gubernur Jawa Barat Nomor 92 Tahun 2014, tetap dinyatakan berlaku hingga berakhirnya masa berlaku perizinan. Untuk itu kepada seluruh kabupaten/kota segera melakukan penyesuaian berdasarkan tahapan kewenangan urusan pemerintahan melalui pencabutan izin sesuai ketentuan yang berlaku.

2) Menyampaikan daftar dan dokumen perizinan yang telah diterbitkan sebagaimana poin 1 dan 2 oleh Operasional Perangkat Daerah (OPD) yang menangani peizinan di daerah kabupaten/kota kepada Gubernur Jawa Barat, untuk optimalnya perizinan.

3) Menyampaikan informasi tentang perubahan kewenangan penerbitan perizinan kepada masyarakat/pemohon izin untuk segera menyesuaikan dan berkoordinasi dengan Badan Penanaman Modal dan Perijinan Terpadu Provinsi Jawa Barat serta Biro Investasi dan BUMD Sekretariat Daerah Provinsi Jawa Barat Untuk menangani pemasalahan dan kendala dalam pelaksanaan pelayanan perizinan.

\section{ANALISIS \\ Pertambangan Mineral dan Batubara Pasca Pem- berlakuan Undang-Undang No. 23 Tahun 2014}

\section{Bidang Umum}

Menurut Pasal 9 UU 23/2014, urusan pemerintahan terdiri atas urusan pemerintahan: absolut, konkuren, dan umum. Urusan pemerintahan absolut sepenuhnya kewenangan pemerintah pusat, sementara urusan pemerintahan konkuren dibagi antara pemerintah pusat dan daerah provinsi dan daerah kabupaten/kota yang merupakan dasar dari pelaksanaan otonomi daerah. Sedangkan urusan pemerintahan umum adalah urusan pemerintahan yang menjadi kewenangan Presiden sebagai kepala pemerintahan.

Mencermati lebih jauh tentang urusan pemerintahan konkuren, Pasal 12 undang-undang ini membaginya menjadi dua bagian, yaitu urusan pemerintahan wajib dan urusan pemerintahan pilihan. Urusan pemerintahan wajib adalah urusan pemerintahan yang wajib dilaksanakan oleh semua daerah, terdiri atas pelayanan dasar dan pelayanan nondasar. Sedangkan urusan pemerintahan pilihan berupa urusan pemerintahan yang diselenggarakan oleh daerah sesuai dengan potensi yang dimiliki oleh masing-masing daerah. Urusan pemerintahan pilihan meliputi bidang: (a) kelautan dan perikanan; (b) pariwisata; (c) pertanian; (d) kehutanan; (e) energi dan sumber daya mineral; (f) perdagangan; (g) perindustrian; dan (h) transmigrasi (Gambar 1).

Pembagian urusan pemerintahan konkuren antara pemerintah pusat dan daerah provinsi serta daerah kabupaten/kota sebagaimana disebutkan di atas didasarkan pada prinsip akuntabilitas, efisiensi, dan eksternalitas, serta kepentingan strategis nasional. Berikut kriteria-kriteria urusan pemerintahan pusat, daerah provinsi, dan daerah kabupaten/kota.

Kriteria urusan pemerintahan yang menjadi kewenangan pemerintah pusat adalah:

a. urusan pemerintahan yang lokasinya lintas daerah provinsi atau lintas negara.

b. urusan pemerintahan yang penggunanya lintas daerah provinsi atau lintas negara.

c. urusan pemerintahan yang manfaat atau dampak negatifnya lintas daerah provinsi atau lintas negara.

d. urusan pemerintahan yang penggunaan sumber dayanya lebih efisien apabila dilakukan oleh pemerintah pusat, dan/atau 


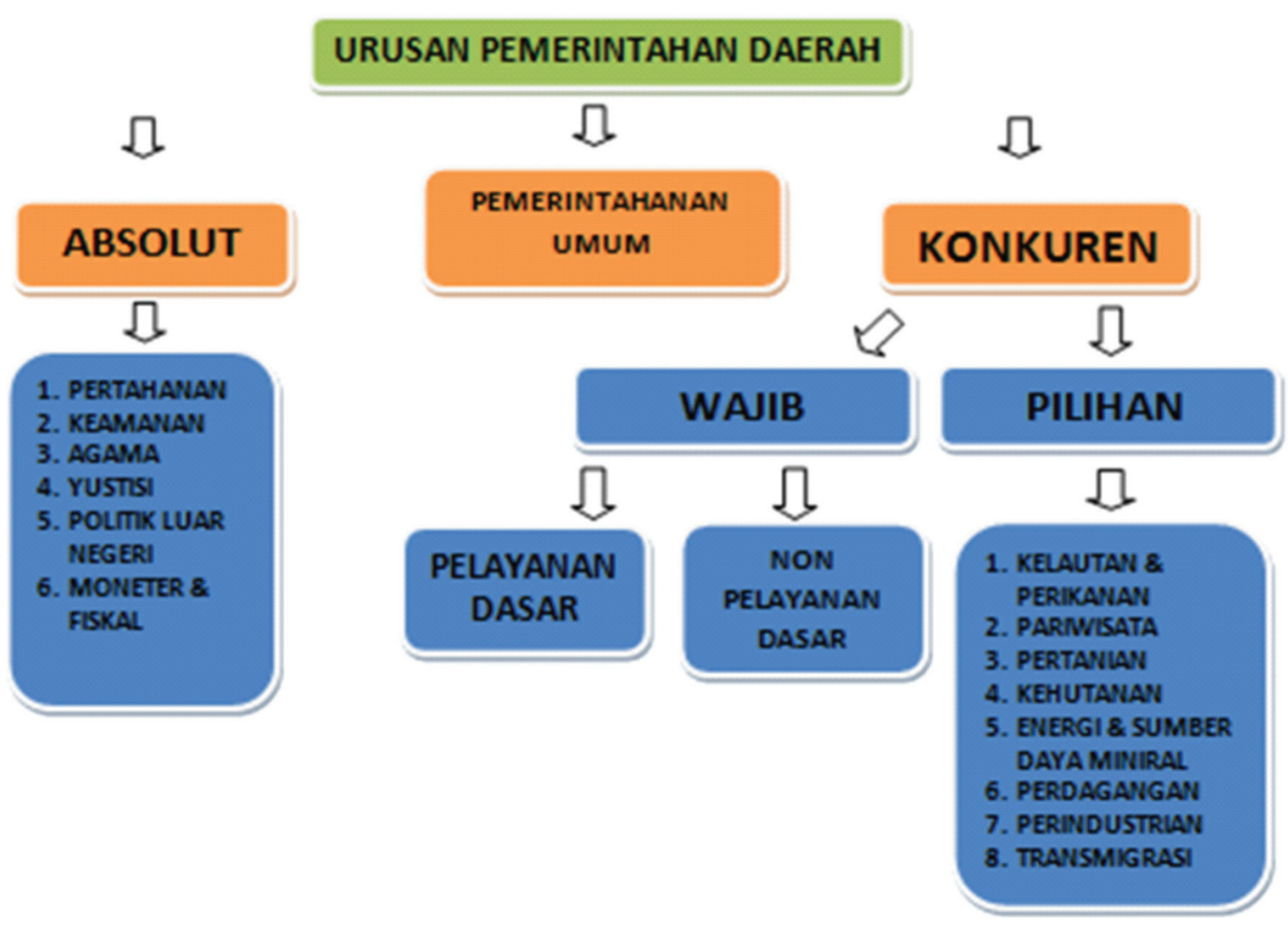

Gambar 1. Urusan pemerintahan

e. urusan pemerintahan yang peranannya strategis bagi kepentingan nasional.

Kriteria urusan pemerintahan yang menjadi kewenangan pemerintah daerah provinsi adalah:

a. urusan pemerintahan yang lokasinya lintas kabupaten/kota.

b. urusan pemerintahan yang penggunanya lintas daerah kabupaten/kota.

c. urusan pemerintahan yang manfaat atau dampak negatifnya lintas daerah kabupaten/ kota, dan/atau

d. urusan pemerintahan yang penggunaan sumber dayanya lebih efisien apabila dilakukan oleh daerah provinsi.

Kriteria urusan pemerintahan yang menjadi kewenangan pemerintah daerah kabupaten/kota adalah:

a. urusan pemerintahan yang lokasinya dalam daerah kabupaten/kota.

b. urusan pemerintahan yang penggunanya dalam daerah kabupaten/kota.

c. urusan pemerintahan yang manfaat atau dampak negatifnya hanya dalam daerah kabupaten/kota; dan/atau urusan pemerintahan yang penggunaan sumber dayanya lebih efisien apabila dilakukan oleh daerah kabupaten/kota.

Kriteria urusan pemerintahan yang menjadi kewenangan pemerintah daerah provinsi adalah:

a. urusan pemerintahan yang lokasinya lintas daerah kabupaten/kota.

b. urusan pemerintahan yang penggunanya lintas daerah kabupaten/kota.

c. urusan pemerintahan yang manfaat atau dampak negatifnya lintas daerah kabupaten/ kota, dan/atau

d. urusan pemerintahan yang penggunaan sumber dayanya lebih efisien apabila dilakukan oleh daerah provinsi.

Kriteria urusan pemerintahan yang menjadi kewenangan pemerintah daerah kabupaten/kota adalah:

a. urusan pemerintahan yang lokasinya dalam daerah kabupaten/kota. 
b. urusan pemerintahan yang penggunanya dalam daerah kabupaten/kota.

c. urusan pemerintahan yang manfaat atau dampak negatifnya hanya dalam daerah kabupaten/kota, dan/atau

d. urusan pemerintahan yang penggunaan sumber dayanya lebih efisien apabila dilakukan oleh daerah kabupaten/kota.

Ketentuan mengenai pembagian urusan pemerintahan daerah dan pemerintah pusat dalam urusan pilihan adalah sebagai berikut:

a. penyelenggaraan urusan pemerintahan bidang kehutanan, kelautan, serta energi dan sumber daya mineral dibagi antara pemerintah pusat dan pemerintah daerah.

b. urusan pemerintahan bidang kehutanan yang berkaitan dengan pengelolaan taman hutan raya kabupaten/kota menjadi kewenangan daerah kabupaten/kota.

c. urusan pemerintahan bidang energi dan sumber daya mineral yang berkaitan dengan pengelolaan minyak dan gas bumi menjadi kewenangan pemerintah pusat.

d. urusan pemerintahan bidang energi dan sumber daya mineral yang berkaitan dengan pemanfaatan langsung panas bumi dalam daerah kabupaten/kota menjadi kewenangan daerah kabupaten/kota.

\section{Bidang Energi dan Sumber Daya Mineral}

Sebagaimana tercantum dalam Pasal 12 UU 23/2014, salah satu urusan pemerintahan pilihan adalah di bidang energi dan sumber daya mineral yang dibagi antara pemerintah pusat, pemerintah provinsi, dan pemerintah kabupaten/kota. Bidang energi dan sumber daya mineral dikelompokkan menjadi suburusan geologi, mineral dan batubara, minyak dan gas bumi, energi baru terbarukan, dan ketenagalistrikan. Dari kelima suburusan tersebut, suburusan energi baru terbarukan yang melibatkan pemerintah daerah kabupaten/kota, yaitu penerbitan izin pemanfaatan langsung panas bumi. Sementara suburusan lainnya oleh pemerintah pusat dan pemerintah provinsi, kecuali suburusan minyak dan gas bumi yang hanya dikelola oleh pemerintah pusat.

\section{Hasil Survei}

Dalam rangka kajian implementasi UU 23/2014 terhadap pengembangan mineral dan batubara di Indonesia, dilakukan survei lapangan pada empat provinsi dengan sampel kabupaten/kota, yaitu: Jawa
Barat, Jawa Timur, Kepulauan Bangka Belitung, dan Kalimantan Selatan. Berikut disampaikan hasil survei sebagaimana diuraikan di bawah ini.

\section{Provinsi Jawa Barat}

\section{Kondisi Pertambangan Mineral dan Batubara}

Potensi bahan tambang di Provinsi Jawa Barat sangat besar, mencapai 29 jenis mineral dan batubara yang terdiri atas 17 mineral bukan logam (andesit, kapur, bentonit, diatome, felspar, fosfat, kaolin, marmer, pasir urug, sirtu, kuarsa, tanah liat, tras, zeolit, gipsum, belerang, kalsit); delapan mineral logam (pasir besi, bijih besi, galena, emas, perak, mangan, tembaga, seng); dan empat mineral batuan (batu permata, oniks, batu ares dan obsidian), dan batubara. Seluruh potensi tersebut tersebar di 19 kabupaten, yang telah diusahakan oleh 131 izin usaha logam, 93 izin usaha bukan logam dan 555 izin usaha batuan, dengan total izin usaha pertambangan berjumlah 779 buah (Tabel 1).

Penerimaan daerah dari pertambangan mineral dan batubara selama tahun 2003-2014 (Gambar 2), terus memperlihatkan peningkatan, dari Rp. 2,67 miliar (2003) menjadi Rp. 6,38 miliar (2014). Penerimaan ini sebenarnya relatif kecil jika dibandingkan dengan jumlah IUP yang cukup banyak (total ada 779 buah) serta keberadaan sumber daya mineral dan batubara yang mencakup wilayah seluas 35.222,18 km².

\section{Pengelolaan Pertambangan Pasca Pemberlakuan UU 23/2014}

Survei di Provinsi Jawa Barat, selain ke Dinas Pertambangan dan Energi Provinsi Jawa Barat, juga di tingkat kabupaten/kota dengan mengambil sampel Kabupaten-kabupaten: Cianjur, Tasikmalaya, Garut, dan Sukabumi. Secara umum, sektor pertambangan dan energi dikelola dengan baik. Hal ini terbukti dengan adanya karyawan yang terdiri atas sarjana dari berbagai latar belakang pendidikan, peralatan laboratorium dan lapangan, serta anggaran yang cukup memadai. Persoalan yang terjadi setelah diberlakukannya UU 23/2014 di Provinsi Jawa Barat, yaitu:

1) Perizinan terhambat provinsi (belum adanya standard operating procedure (SOP), peraturan, peraturan pemerintah (PP) yang mengatur undang-undang ini.

2) Dampak kerusakan lingkungan akan lebih besar, karena keterbatasan personil untuk melakukan pengawasan pengusahaan tambang ke seluruh kabupaten. 


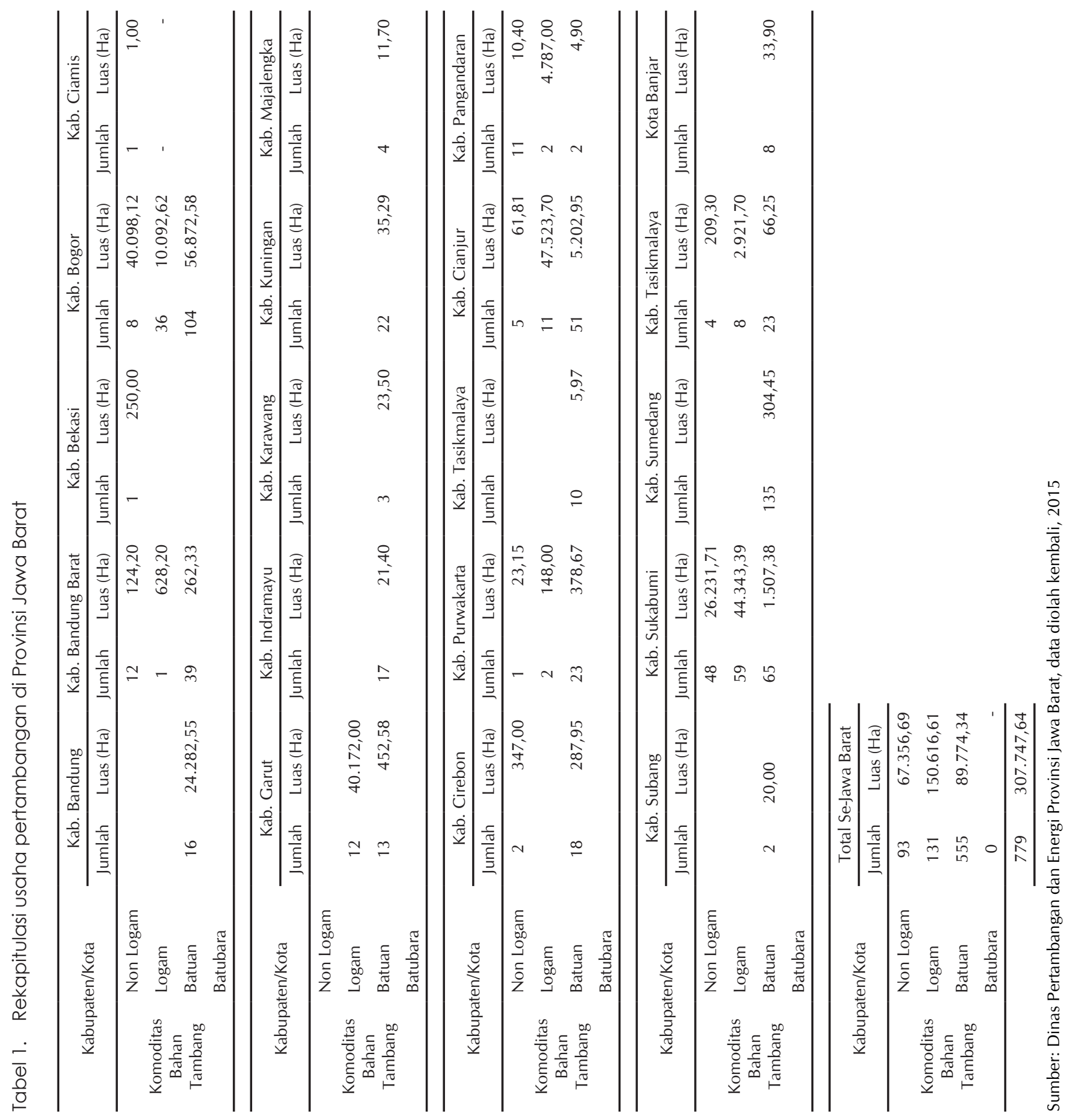




\begin{tabular}{lrrrr}
\hline \multirow{2}{*}{ No } & \multirow{2}{*}{ Tahun } & \multicolumn{2}{c}{ Realisasi } & \multirow{2}{*}{ Total (Rp) } \\
\cline { 3 - 4 } & & Landrent (Rp) & Royalti (Rp) & \\
\hline 1 & 2003 & $37,439,530$ & $2,636,120,816$ & $2,673,560,346$ \\
2 & 2004 & $81,204,881$ & $3,877,396,754$ & $3,958,601,635$ \\
3 & 2005 & $44,795,392$ & $3,356,756,206$ & $3,401,551,598$ \\
4 & 2006 & $75,858,124$ & $3,337,677,917$ & $3,413,536,041$ \\
5 & 2007 & $38,196,192$ & $5,201,148,681$ & $5,239,344,873$ \\
6 & 2008 & $28,694,920$ & $2,726,793,370$ & $2,755,488,290$ \\
7 & 2009 & $12,955,094$ & $3,011,085,999$ & $3,024,041,093$ \\
8 & 2010 & $50,892,070$ & $4,509,917,257$ & $4,560,809,327$ \\
9 & 2011 & $202,086,745$ & $5,515,045,435$ & $5,717,132,180$ \\
10 & 2012 & $270,446,648$ & $5,337,293,316$ & $5,607,739,964$ \\
11 & 2013 & $512,132,191$ & $4,522,023,558$ & $5,034,155,749$ \\
12 & 2014 & $620,138,632$ & $5,764,933,570$ & $6,385,072,202$ \\
\hline
\end{tabular}

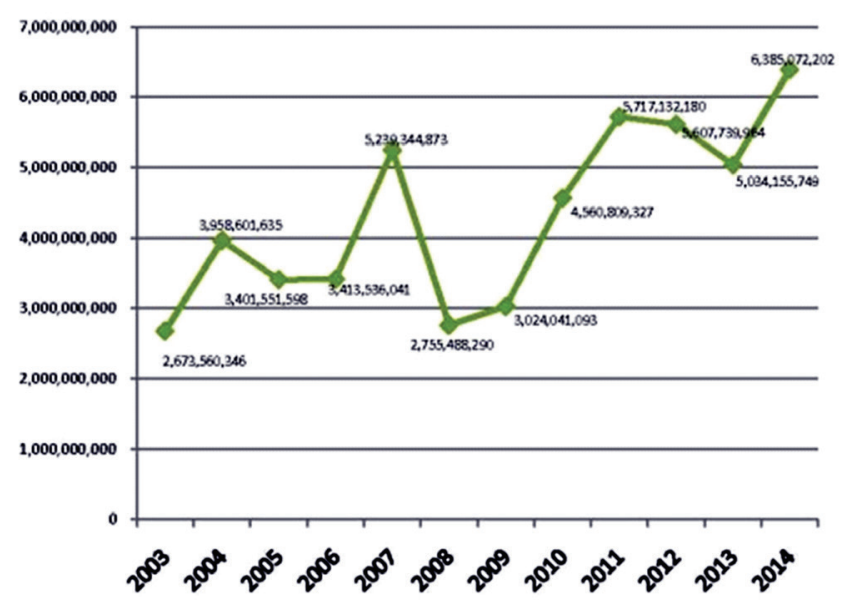

Sumber: Dinas Pertambangan dan Energi Provinsi Jawa Barat, data diolah kembali, 2015

Gambar 2. Grafik realisasi bagi hasil sektor pertambangan umum bagi Provinsi tahun 2003-2014

3) Dinas Pertambangan dan Energi kabupaten/ kota memiliki anggaran, tetapi tidak dapat dilaksanakan, sementara provinsi dari segi anggaran belum ada, personil terbatas, tidak mungkin melaksanakan tugasnya dengan baik.

4) Penerimaan Negara Bukan Pajak dari sektor mineral dan batubara akan turun yang berdampak terhadap dana bagi hasil untuk kabupaten/kota.

5) Pertambangan Tanpa Izin (PETI) akan marak lagi.

6) Para pegawai di kabupaten/kota banyak menganggur (karena semakin sedikitnya tugas dan fungsi yang bisa dikerjakan), menjadikan keresahan bagi para pejabat dinas pertambangan dan energi di seluruh kabupaten/kota.

7) Risiko tidak dapat menyelesaikan presentasi Rencana Kerja dan Aanggaran Belanja (RKAB) dan Rencana Kerja Tahunan Teknis dan Lingkungan (RKKTL), karena jumlah IUP terlalu banyak yang harus dilaksanakan oleh provinsi.

\section{Provinsi Jawa Timur}

\section{Kondisi Pertambangan Mineral dan Batubara}

Potensi bahan tambang sangat besar, terdiri atas 12 mineral batuan (andesit, breksi, diorit, gamping, marmer, oniks, pasir, sirtu, tanah liat, tanah urug, tras, dan tuf); enam mineral logam (besi, emas, mangan, pasir besi, pirit dan seng); 12 mineral bukan logam (pasir kuarsa, yodium, belerang, fosfat, zeolit, felspar, bentonit, gipsum, dolomit, kalsit, rijang, pirofilit dan oker), dan batubara. Seluruh potensi tersebut tersebar di 29 kabupaten, dengan jumlah IUP sebanyak 512 IUP.

\section{Pengelolaan Pertambangan Pasca Pemberlakuan UU 23/2014}

Survei di Provinsi Jawa Timur selain dilakukan ke Dinas Pertambangan dan Energi Provinsi Jawa Timur, juga di tingkat kabupaten/kota dengan mengambil sampel Kabupaten Malang dan Kabupaten Sidoarjo. Pengelolaan pertambangan mineral dan batubara di Provinsi Jawa Timur ditangani oleh tenaga pelaksana sebanyak 116 orang dari berbagai disiplin ilmu dengan tingkat pendidikan dari sekolah lanjutan tingkat atas sampai sarjana serta didukung oleh peralatan laboratorium dan lapangan.

Alokasi penyaluran Dana Bagi Hasil (DHB) pertambangan mineral dan batubara tahun 2014 di Provinsi Jawa Timur seluruhnya Rp.691.013.00, terdiri atas iuran tetap Rp.168.465.000 dan iuran produksi sebesar Rp.528.548.000.

Pasca pemberlakuan UU 23/2014, hubungan antara provinsi dan kabupaten/kota menjadi kurang harmonis disebabkan kesulitan penggunaan anggaran, pengelolaan sumber daya manusia tidak efisien, koordinasi kegiatan antara pemerintah provinsi dan pemerintah kabupaten/kota belum dinamis karena belum adanya PP sebagai turunan undangundang tersebut sebagai payung hukum untuk 
dapat melaksanakannya. Secara rinci persoalan yang terjadi adalah:

a) Pemerintah pusat segera menerbitkan PP sebagai pedoman pelaksanaan UU 23/2014, khususnya terkait penyerahan P3D.

b) Selama penyerahan P3D dari Dinas Pertambangan dan Energi kabupaten/kota ke Dinas Pertambangan dan Energi provinsi belum selesai agar Dinas Pertambangan dan Energi kabupaten/kota tetap diberikan kewenangan melaksanakan suburusan pertambangan dan energi sesuai UU 4/2009, terkecuali perizinan dan turunannya.

c) Selambat-lambatnya Maret 2017 Dinas Pertambangan dan Energi provinsi sudah membentuk Unit Pelayanan Terpadu (UPT) atau dinas pembantuan untuk melaksanakan tugas-tugas pembinaan dan pengawasan terhadap IUP yang sudah ada.

d) Segera memetakan tenaga pengawas tambang yang memiliki kompetensi yang ada di kabupaten/kota.

e) Segera memetakan tenaga pengawas tambang yang memiliki kompetensi yang ada di kabupaten/kota.

f) Perlu adanya petunjuk yang jelas terhadap mekanisme penyerahan personil, khusus terhadap pegawai nonteknis.

g) Perizinan pemanfaatan air tanah, penetapan cekungan air tanah dan penetapan nilai air tanah menjadi kewenangan provinsi, sementara pajak air tanah selama ini kabupaten yang memungut.

\section{Provinsi Kalimantan Selatan}

\section{Kondisi Pertambangan Mineral dan Batubara}

Kalimantan Selatan merupakan salah satu produsen batubara di Indonesia. Sumber daya batubara terukur pada perusahaan Perjanjian Karya Pengusahaan Pertambangan Batubara (PKP2B) di Provinsi Kalimantan Selatan sebesar 4.232,86 juta ton dengan cadangan terbukti 2.319,29 juta ton. Rencana produksi perusahaan PKP2B tahun 2015 seluruhnya sebesar 118,12 juta ton dan rencana penjualan sebesar 109,43 juta ton (Tabel 2). Sedangkan sumber daya batubara terukur sebesar 1.009,55 juta ton dengan cadangan terbukti 454,88 juta ton. Rencana produksi perusahaan IUP batubara tahun 2015 sebesar 48,42 juta ton dan rencana penjualan sebesar 47,39 juta ton.

Jumlah pemegang IUP seluruhnya 861 buah, terdiri atas: pemegang IUP 861 buah, pemegang PKP2B
19 buah, dan pemegang Kontrak Karya (KK) 2 buah. Jenis bahan galian yang diusahakan berupa batubara 650 buah, logam 90 buah, dan mineral bukan logam dan batuan 121 buah (Tabel 3). Dari 861 IUP terdapat 423 yang sudah clear and clean $(\mathrm{CnC}), 61$ dalam proses $\mathrm{CnC}$, dan 74 sudah memiliki sertifikat CnC. Sedangkan untuk perusahaan PKP2B seluruhnya sudah CnC. Berdasarkan data Biro Keuangan DESDM dan Dispenda Provinsi Kalimantan Selatan, royalti batubara tahun 2011 di Provinsi Kalimantan Selatan mencapai Rp.2,5 triliun dan nilai landrent sebesar Rp.9,9 miliar. Tahun 2014 nilai royalti batubara mengalami penurunan menjadi Rp.2,2 triliun dan nilai landrent naik menjadi Rp.27,5 milyar (Tabel 4).

\section{Pengelolaan Pertambangan Pasca Pemberlakuan UU 23/2014}

Survei di Provinsi Kalimantan Selatan, selain dilakukan ke Dinas Pertambangan dan Energi Provinsi Kalimantan Selatan, di tingkat kabupaten/kota juga diambil sampel Kabupaten Banjar, dan Kabupaten Banjarbaru. Jumlah pegawai Dinas Pertambangan dan Energi Provinsi Kalimantan Selatan seluruhnya berjumlah 90 orang yang berasal dari berbagai disiplin ilmu dengan tingkat pendidikan dari SLTA sampai sarjana.

Berdasarkan hasil survei, persoalan pengelolaan pascapemberlakuan UU 23/2014 di Provinsi Kalimantan Selatan adalah:

a) Dokumen Pelaksanaan Anggaran (DPA) Kinerja SKPD DESDM telah disahkan oleh dewan, sementara dengan UU 23/2014 DPA tersebut tidak dapat dilaksanakan karena alasan kewenangan sudah tidak dimiliki lagi, maka bagi SKPD yang tidak melaksanakan DPA, dapat penilaian kinerjanya rendah.

b) Risiko tidak dapat menyelesaikan presentasi RKAB dan RKKTL, karena jumlah IUP terlalu banyak yang harus dilaksanakan oleh provinsi.

C) Perizinan terhambat provinsi (belum adanya SOP, peraturan, PP yang mengatur undangundang ini).

d) Dampak kerusakan lingkungan akan lebih besar, karena keterbatasan personil untuk melakukan pengawasan pengusahaan tambang di seluruh kabupaten.

e) Distamben kabupaten/kota memiliki anggaran tetapi tidak dapat dilaksanakan, sementara provinsi dari segi anggaran belum ada, personil terbatas, tidak mungkin melaksanakan tugasnya dengan baik. 


\begin{tabular}{|c|c|c|c|c|c|c|c|c|c|c|c|c|c|c|c|c|c|c|c|c|c|c|c|}
\hline 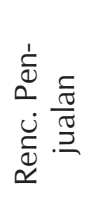 & $\mid \begin{array}{l}8 \\
0 \\
8 \\
8 \\
\dot{8} \\
8 \\
0 \\
1\end{array}$ & & 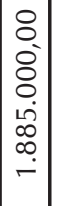 & $\begin{array}{l}8 \\
0 \\
0 \\
0 \\
\\
0 \\
\dot{m} \\
\text { | }\end{array}$ & & $\begin{array}{l}8 \\
0 \\
0 \\
0 \\
0 \\
0 \\
0 \\
0 \\
0\end{array}$ & $\begin{array}{l}8 \\
0 \\
8 \\
. \\
\dot{0} \\
0 \\
\dot{0}\end{array}$ & $\begin{array}{c}8 \\
\dot{0} \\
\dot{0} \\
\dot{1} \\
\dot{1} \\
\infty \\
\infty \\
\infty\end{array}$ & $\begin{array}{l}8 \\
8 \\
\dot{0} \\
8 \\
\dot{8} \\
\dot{0} \\
1 \\
1\end{array}$ & 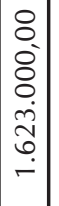 & $\mid \begin{array}{l}8 \\
0 \\
0 \\
0 \\
0 \\
- \\
-\end{array}$ & 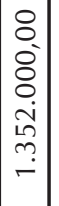 & $\begin{array}{l}8 \\
0 \\
0 \\
0 \\
\dot{2} \\
0 \\
0\end{array}$ & \begin{tabular}{l|}
8 \\
8 \\
8 \\
8 \\
$\dot{8}$ \\
8
\end{tabular} & & 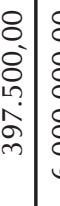 & 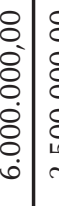 & 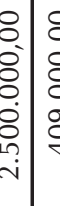 & & 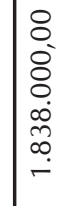 & & & 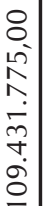 \\
\hline 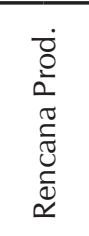 & 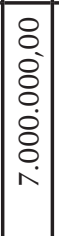 & & 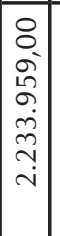 & \begin{tabular}{l|} 
\\
8 \\
0 \\
$\vdots$ \\
0 \\
$\dot{0}$ \\
$\vdots$ \\
$\dot{+}$ \\
|
\end{tabular} & \begin{tabular}{l|} 
\\
8 \\
0 \\
0 \\
0 \\
0 \\
1 \\
$\infty$
\end{tabular} & $\begin{array}{l} \\
8 \\
0 \\
\tilde{0} \\
0 \\
0 \\
0 \\
0 \\
0\end{array}$ & $\begin{array}{l}8 \\
8 \\
8 \\
8 \\
: \\
0 \\
0 \\
0\end{array}$ & \begin{tabular}{|c|} 
\\
0 \\
$i$ \\
$o$ \\
0 \\
0 \\
0 \\
$\infty$ \\
$\infty$ \\
$\infty$
\end{tabular} & 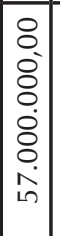 & 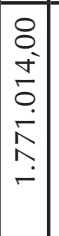 & & 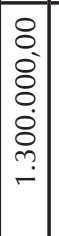 & $\begin{array}{l}8 \\
8 \\
0 \\
0 \\
\hat{n} \\
\end{array}$ & \begin{tabular}{l|l} 
& \\
8 \\
8 \\
$\vdots$ \\
$\vdots$ \\
$\dot{2}$ \\
$\sigma$
\end{tabular} & & 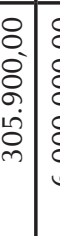 & \begin{tabular}{l|l}
8 & \\
8 & \\
$\vdots$ & \\
$\vdots$ & \\
$\vdots$ & \\
$\vdots$ & \\
0 & \\
&
\end{tabular} & 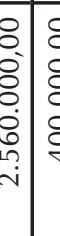 & & 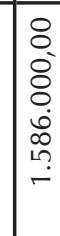 & & & \\
\hline 童 & 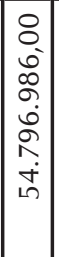 & & \begin{tabular}{|c|}
8 \\
0 \\
0 \\
0 \\
$\dot{0}$ \\
0 \\
$\infty$ \\
$\infty$
\end{tabular} & $\begin{array}{l}8 \\
0 \\
0 \\
0 \\
\dot{0} \\
m \\
\dot{m} \\
\dot{m}\end{array}$ & $\begin{array}{l}8 \\
0 \\
0 \\
0 \\
0 \\
0 \\
1 \\
1\end{array}$ & 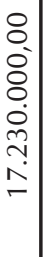 & $\begin{array}{l}8 \\
8 \\
8 \\
8 \\
\dot{0} \\
\stackrel{0}{0} \\
\dot{y}\end{array}$ & 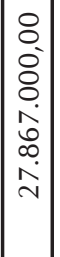 & 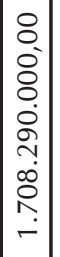 & 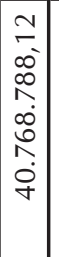 & & \begin{tabular}{|l|} 
\\
0 \\
0 \\
0 \\
0 \\
$\dot{0}$ \\
$n$ \\
$m$
\end{tabular} & $\begin{array}{l}8 \\
8 \\
0 \\
0 \\
\dot{0} \\
\stackrel{1}{1} \\
i \\
i\end{array}$ & 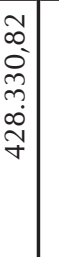 & & $\begin{array}{l}0 \\
0 \\
0 \\
0 \\
0 \\
\vdots \\
\vdots \\
n \\
n\end{array}$ & 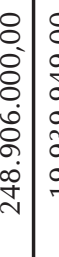 & \begin{tabular}{l|l}
8 & 5 \\
0 & 5 \\
0 & \\
0 & 5 \\
0 & 5 \\
0 & \\
0 &
\end{tabular} & & 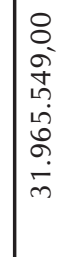 & 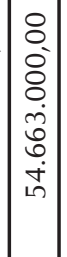 & & 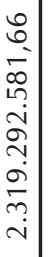 \\
\hline 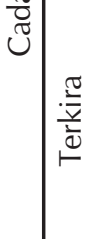 & 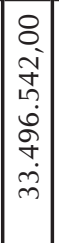 & & \begin{tabular}{l|}
8 \\
8 \\
$\circ$ \\
8 \\
$\dot{1}$ \\
\\
\end{tabular} & $\begin{array}{l}8 \\
0 \\
\dot{8} \\
\dot{m} \\
\hat{n} \\
\dot{m}\end{array}$ & $\begin{array}{l}8 \\
0 \\
8 \\
\dot{1} \\
\\
6\end{array}$ & $\begin{array}{l}8 \\
0 \\
0 \\
+ \\
0 \\
0 \\
0\end{array}$ & $\begin{array}{l}8 \\
8 \\
\dot{8} \\
0 \\
\dot{0} \\
\hat{b} \\
\dot{\omega}\end{array}$ & 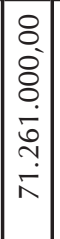 & 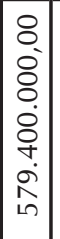 & & \begin{tabular}{|c|}
8 \\
$\omega$ \\
2 \\
0 \\
$\sigma$ \\
\\
\\
\end{tabular} & & 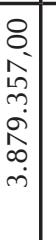 & & & & 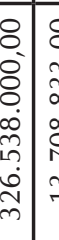 & 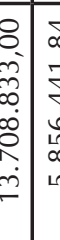 & & 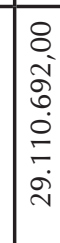 & $\mid \begin{array}{l}8 \\
0 \\
0 \\
0 \\
\infty \\
0 \\
0 \\
\dot{1} \\
\end{array}$ & & 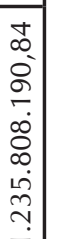 \\
\hline 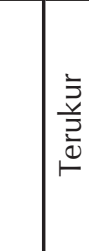 & 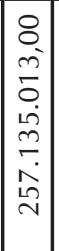 & & 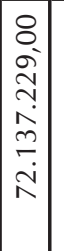 & 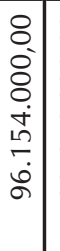 & $\begin{array}{l}8 \\
0 \\
0 \\
0 \\
\dot{1} \\
\dot{0} \\
\infty\end{array}$ & \begin{tabular}{c|}
8 \\
0 \\
$\vdots$ \\
$\dot{0}$ \\
0 \\
+ \\
0
\end{tabular} & 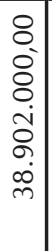 & \begin{tabular}{|c|} 
\\
8 \\
0 \\
8 \\
8 \\
$\dot{0}$ \\
$\infty$ \\
\hdashline \\
$\infty$ \\
\end{tabular} & $\begin{array}{l}8 \\
8 \\
8 \\
8 \\
0 \\
8 \\
8 \\
0 \\
\dot{0} \\
\stackrel{0}{2} \\
ن \\
ن\end{array}$ & 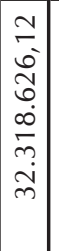 & 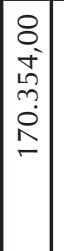 & 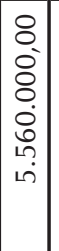 & 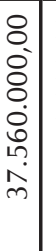 & 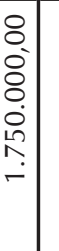 & & 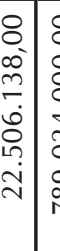 & 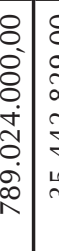 & 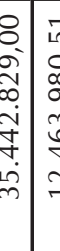 & & 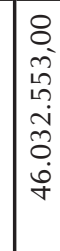 & \begin{tabular}{|l|} 
\\
0 \\
0 \\
0 \\
0 \\
0 \\
0 \\
0 \\
\\
\end{tabular} & & 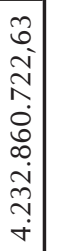 \\
\hline 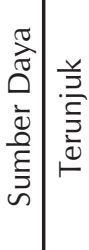 & 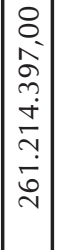 & & 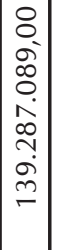 & 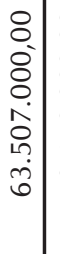 & $\begin{array}{l}8 \\
0 \\
0 \\
0 \\
0 \\
0 \\
0 \\
\dot{0}\end{array}$ & $\begin{array}{l}0 \\
0 \\
0 \\
0 \\
0 \\
0 \\
\dot{1} \\
i n\end{array}$ & $\begin{array}{l}8 \\
0 \\
8 \\
0 \\
\dot{\vdots} \\
0 \\
\dot{0}\end{array}$ & $\left|\begin{array}{c}8 \\
\dot{0} \\
\dot{8} \\
0 \\
\dot{1} \\
\dot{0} \\
\dot{0} \\
\dot{+}\end{array}\right|$ & 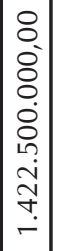 & 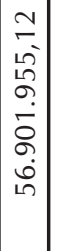 & $\mid \begin{array}{c}8 \\
0 \\
\hat{0} \\
i \\
0 \\
0 \\
0 \\
-\end{array}$ & 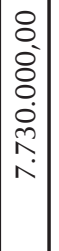 & 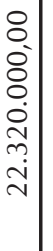 & 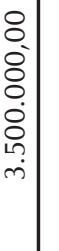 & & 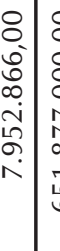 & 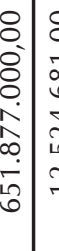 & 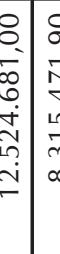 & & 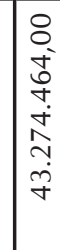 & 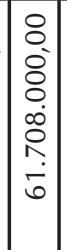 & & 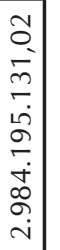 \\
\hline 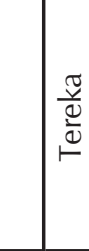 & $\left|\begin{array}{c}0 \\
0 \\
\infty \\
\infty \\
0 \\
0 \\
0 \\
0 \\
\infty \\
\infty \\
\infty \\
m\end{array}\right|$ & & 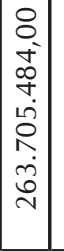 & 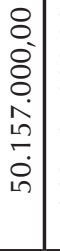 & $\begin{array}{l}8 \\
0 \\
0 \\
0 \\
\dot{0} \\
9 \\
0 \\
0 \\
0 \\
1\end{array}$ & $\begin{array}{l}8 \\
0 \\
0 \\
0 \\
\vdots \\
\vdots \\
\vdots \\
1 \\
0 \\
0\end{array}$ & $\begin{array}{l}8 \\
8 \\
\vdots \\
0 \\
\dot{0} \\
\grave{1} \\
\hat{m} \\
=\end{array}$ & $\left|\begin{array}{l}8 \\
0 \\
0 \\
8 \\
0 \\
\dot{0} \\
0 \\
0 \\
0 \\
0 \\
i\end{array}\right|$ & $\mid$\begin{tabular}{c}
8 \\
8 \\
8 \\
8 \\
0 \\
8 \\
$\circ$ \\
\hdashline \\
$\dot{1}$ \\
$m$ \\
-1
\end{tabular} & \begin{tabular}{|c|}
0 \\
0 \\
0 \\
0 \\
0 \\
$\infty$ \\
$\sim \hat{n}$ \\
0 \\
1
\end{tabular} & & $\begin{array}{c}8 \\
0 \\
0 \\
0 \\
0 \\
\dot{0} \\
0 \\
\dot{0} \\
0\end{array}$ & $\begin{array}{l}8 \\
0 \\
0 \\
0 \\
\dot{1} \\
+ \\
\infty\end{array}$ & $\begin{array}{l}8 \\
\vdots \\
8 \\
0 \\
\dot{0} \\
8 \\
0 \\
1\end{array}$ & & 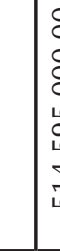 & 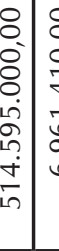 & 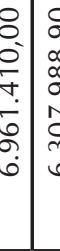 & & 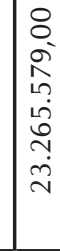 & & & 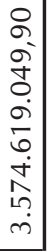 \\
\hline 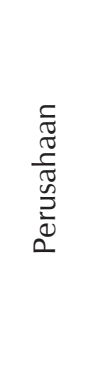 & 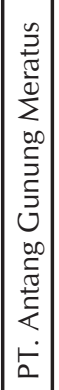 & 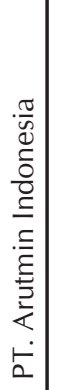 & 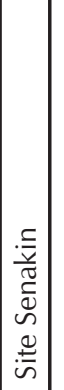 & 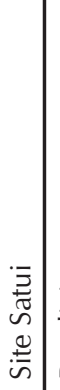 & 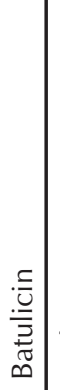 & $\bar{\Sigma}$ & 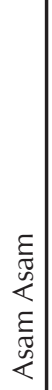 & 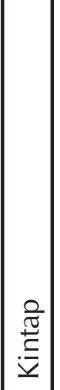 & 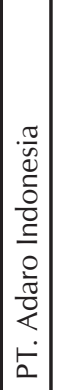 & 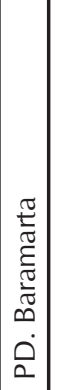 & 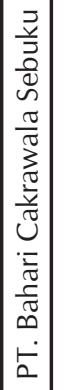 & 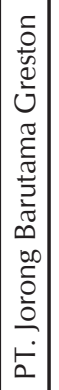 & 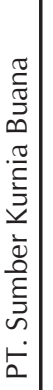 & 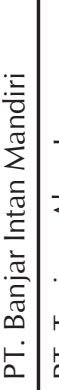 & 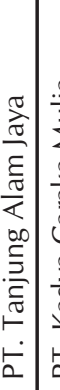 & 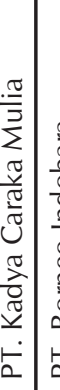 & 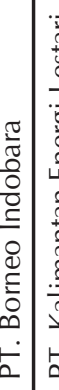 & 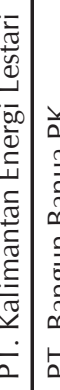 & 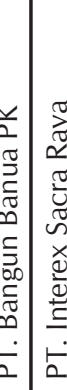 & 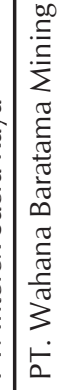 & 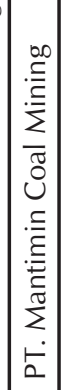 & 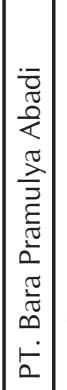 & $\begin{array}{l}\bar{\pi} \\
\text { 이 }\end{array}$ \\
\hline ż & - & $\sim$ & & & & & & & $m$ & + & in & 0 & $\Lambda$ & $\infty$ & $\sigma$ & $\circ=$ & $=?$ & 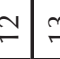 & $m \pm$ & $\stackrel{\llcorner}{\llcorner}$ & $\div$ & 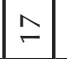 & \\
\hline
\end{tabular}


Tabel 3. Rekapitulasi IUP per Kabupaten di Provinsi Kalimantan Selatan tahun 2015

\begin{tabular}{|c|c|c|c|c|c|c|c|c|c|c|}
\hline \multirow{4}{*}{ No } & \multirow{4}{*}{ Kabupaten/Kota } & \multicolumn{4}{|c|}{ KOMODITAS BATUBARA } & \multirow{4}{*}{ Jumlah } & \multirow{2}{*}{\multicolumn{4}{|c|}{ Keterangan }} \\
\hline & & \multirow{2}{*}{\multicolumn{2}{|c|}{$\begin{array}{c}\text { IUP Eksplorasi } \\
\text { Perizinan }\end{array}$}} & \multirow{2}{*}{\multicolumn{2}{|c|}{$\frac{\text { IUP Operasi Produksi }}{\text { Perizinan }}$}} & & & & & \\
\hline & & & & & & & \multirow{2}{*}{$\begin{array}{l}\mathrm{BIm} \\
\mathrm{CNC}\end{array}$} & \multirow{2}{*}{$\begin{array}{l}\text { Sdh } \\
\text { CNC }\end{array}$} & \multirow{2}{*}{$\begin{array}{l}\text { Proses } \\
\text { CNC }\end{array}$} & \multirow{2}{*}{$\begin{array}{l}\text { Sertifikat } \\
\text { CNC }\end{array}$} \\
\hline & & Habis & Berlaku & Habis & Berlaku & & & & & \\
\hline 1 & Kotabaru & 34 & 10 & 31 & 22 & 97 & 25 & 72 & 0 & 12 \\
\hline 2 & Tanah Bumbu & 29 & 48 & 48 & 167 & 292 & 139 & 136 & 17 & 22 \\
\hline 3 & Tanah Laut & 39 & 4 & 3 & 86 & 132 & 57 & 62 & 14 & 18 \\
\hline 4 & Banjar & 0 & 16 & 5 & 32 & 53 & 10 & 36 & 8 & 7 \\
\hline 5 & Tapin & 0 & 0 & 0 & 25 & 25 & 0 & 25 & 0 & 6 \\
\hline 6 & Hulu Sungai Selatan & 2 & 0 & 0 & 1 & 3 & 0 & 3 & 0 & 1 \\
\hline 7 & Hulu Sungai Tengah & 0 & 0 & 0 & 0 & 0 & 0 & 0 & 0 & 0 \\
\hline 8 & Hulu Sungai Utara & 0 & 0 & 0 & 0 & 0 & 0 & 0 & 0 & 0 \\
\hline 9 & Balangan & 0 & 25 & 0 & 3 & 28 & 1 & 27 & 0 & 2 \\
\hline 10 & Tabalong & 3 & 1 & 0 & 16 & 20 & 3 & 10 & 7 & 6 \\
\hline 11 & Barito Kuala & 0 & 0 & 0 & 0 & 0 & 0 & 0 & 0 & 0 \\
\hline 12 & Banjarmasin & 0 & 0 & 0 & 0 & 0 & 0 & 0 & 0 & 0 \\
\hline 13 & Banjarbaru & 0 & 0 & 0 & 0 & 0 & 0 & 0 & 0 & 0 \\
\hline & SUB TOTAL & 107 & 104 & 87 & 352 & 650 & 235 & 371 & 46 & 74 \\
\hline \multirow{4}{*}{ No } & \multirow{4}{*}{ Kabupaten/Kota } & \multicolumn{4}{|c|}{ KOMODITAS MINERAL } & \multirow{4}{*}{ Jumlah } & \multirow{2}{*}{\multicolumn{4}{|c|}{ Keterangan }} \\
\hline & & \multicolumn{2}{|c|}{ IUP Eksplorasi } & \multicolumn{2}{|c|}{ IUP Operasi Produksi } & & & & & \\
\hline & & \multicolumn{2}{|c|}{ Perizinan } & \multicolumn{2}{|c|}{ Perizinan } & & \multirow{2}{*}{$\begin{array}{l}\mathrm{BIm} \\
\mathrm{CNC}\end{array}$} & \multirow{2}{*}{$\begin{array}{l}\text { Sdh } \\
\text { CNC }\end{array}$} & \multirow{2}{*}{$\begin{array}{l}\text { Proses } \\
\mathrm{CNC}\end{array}$} & \multirow{2}{*}{$\begin{array}{l}\text { Sertifikat } \\
\text { CNC }\end{array}$} \\
\hline & & Habis & Berlaku & Habis & Berlaku & & & & & \\
\hline 1 & Kotabaru & 2 & 2 & 0 & 11 & 15 & 6 & 9 & 0 & 0 \\
\hline 2 & Tanah Bumbu & 3 & 0 & 2 & 6 & 11 & 5 & 6 & 0 & 0 \\
\hline 3 & Tanah Laut & 2 & 6 & 1 & 23 & 32 & 24 & 5 & 3 & 0 \\
\hline 4 & Banjar & 4 & 7 & 0 & 9 & 20 & 17 & 2 & 1 & 0 \\
\hline 5 & Tapin & 0 & 0 & 0 & 2 & 2 & 1 & 1 & 0 & 0 \\
\hline 6 & Hulu Sungai Selatan & 1 & 0 & 0 & 0 & 1 & 0 & 1 & 0 & 0 \\
\hline 7 & Hulu Sungai Tengah & 0 & 0 & 0 & 0 & 0 & 0 & 0 & 0 & 0 \\
\hline 8 & Hulu Sungai Utara & 0 & 0 & 0 & 0 & 0 & 0 & 0 & 0 & 0 \\
\hline 9 & Balangan & 0 & 3 & 0 & 2 & 5 & 0 & 5 & 0 & 0 \\
\hline 10 & Tabalong & 3 & 1 & 0 & 0 & 4 & 1 & 2 & 1 & 0 \\
\hline 11 & Barito Kuala & 0 & 0 & 0 & 0 & 0 & 0 & 0 & 0 & 0 \\
\hline 12 & Banjarmasin & 0 & 0 & 0 & 0 & 0 & 0 & 0 & 0 & 0 \\
\hline 13 & Banjarbaru & 0 & 0 & 0 & 0 & 0 & 0 & 0 & 0 & 0 \\
\hline & SUB TOTAL & 15 & 19 & 3 & 53 & 90 & 54 & 31 & 5 & 0 \\
\hline
\end{tabular}


Tabel 3. Rekapitulasi IUP per Kabupaten di Provinsi Kalimantan Selatan tahun 2015

(Lanjutan)

\begin{tabular}{|c|c|c|c|c|c|c|c|c|c|c|}
\hline \multirow{4}{*}{ No } & \multirow{4}{*}{ Kabupaten/Kota } & \multicolumn{4}{|c|}{ KOMODITAS BATUAN } & \multirow{3}{*}{ Jumlah } & \multirow{2}{*}{\multicolumn{4}{|c|}{ Keterangan }} \\
\hline & & \multirow{2}{*}{\multicolumn{2}{|c|}{$\begin{array}{c}\text { IUP Eksplorasi } \\
\text { Perizinan }\end{array}$}} & \multirow{2}{*}{\multicolumn{2}{|c|}{$\begin{array}{c}\text { IUP Operasi Produksi } \\
\text { Perizinan }\end{array}$}} & & & & & \\
\hline & & & & & & & \multirow{2}{*}{$\begin{array}{l}\text { Blm } \\
\text { CNC }\end{array}$} & \multirow{2}{*}{$\begin{array}{l}\mathrm{Sdh} \\
\mathrm{CNC}\end{array}$} & \multirow{2}{*}{$\begin{array}{l}\text { Proses } \\
\text { CNC }\end{array}$} & \multirow{2}{*}{$\begin{array}{l}\text { Sertifikat } \\
\text { CNC }\end{array}$} \\
\hline & & Habis & Berlaku & Habis & Berlaku & & & & & \\
\hline 1 & Kotabaru & 0 & 0 & 22 & 12 & 34 & 34 & 0 & 0 & 0 \\
\hline 2 & Tanah Bumbu & 9 & 6 & 0 & 1 & 16 & 14 & 2 & 0 & 0 \\
\hline 3 & Tanah Laut & 0 & 2 & 0 & 22 & 24 & 22 & 2 & 0 & 0 \\
\hline 4 & Banjar & 0 & 0 & 0 & 22 & 22 & 13 & 9 & 0 & 0 \\
\hline 5 & Tapin & 0 & 0 & 3 & 0 & 3 & 0 & 3 & 0 & 0 \\
\hline 6 & Hulu Sungai Selatan & 0 & 0 & 0 & 0 & 0 & 0 & 0 & 0 & 0 \\
\hline 7 & Hulu Sungai Tengah & 0 & 0 & 0 & 0 & 0 & 0 & 0 & 0 & 0 \\
\hline 8 & Hulu Sungai Utara & 0 & 0 & 0 & 0 & 0 & 0 & 0 & 0 & 0 \\
\hline 9 & Balangan & 0 & 0 & 0 & 0 & 0 & 0 & 0 & 0 & 0 \\
\hline 10 & Tabalong & 0 & 6 & 3 & 13 & 22 & 7 & 5 & 10 & 0 \\
\hline 11 & Barito Kuala & 0 & 0 & 0 & 0 & 0 & 0 & 0 & 0 & 0 \\
\hline 12 & Banjarmasin & 0 & 0 & 0 & 0 & 0 & 0 & 0 & 0 & 0 \\
\hline \multirow[t]{3}{*}{13} & Banjarbaru & 0 & 0 & 0 & 0 & 0 & 0 & 0 & 0 & 0 \\
\hline & SUB TOTAL & 9 & 14 & 28 & 70 & 121 & 90 & 21 & 10 & 0 \\
\hline & TOTAL & 131 & 137 & 118 & 475 & 861 & 379 & 423 & 61 & 74 \\
\hline
\end{tabular}

Sumber: Dinas Pertambangan dan Energi Provinsi Kalimantan Selatan, data diolah kembali, 2015

Tabel 4. Produksi, royalti dan landrent batubara di Provinsi Kalimantan Selatan, 201 1-2015

\begin{tabular}{lcrrr}
\hline No & Tahun & $\begin{array}{c}\text { Data Produksi } \\
\text { (Ton) }\end{array}$ & Data Royalti (Rp.) & Data Landrent (Rp.) \\
\hline 1 & 2011 & $138,782,205.67$ & 2.5 Triliun (Seluruh Wilayah Kalsel) \\
& & 509,14 Milyar (Provinsi Kalsel) & 9.9 Milyar (Seluruh Wilayah Kalsel) \\
2 & 2012 & $149,495,347.34$ & 2,7 Triliun (Seluruh Wilayah Kalsel) & 9.026 Milyar (Seluruh Wilayah Kalsel) \\
& & & 634 Milyar (Prov. Kalsel) & 2.653 Milyar (Prov Kalsel) \\
3 & 2013 & $163,016,615.41$ & 2.8 Triliun (Seluruh Wilayah Kalsel) & 9,973 Milyar (Seluruh Wilayah Kalsel) \\
& & & 579,2 Milyar (Prov. Kalsel) & 1,99 Milyar (Prov. Kalsel) \\
4 & 2014 & $171,189,904.05$ & 574.996 milyar (Prov. Kalsel) & 27,5 Milyar (Seluruh Wilayah Kalsel) \\
& & & 2.2 Triliun (Seluruh Wilayah Kalsel) & 6,89 Milyar (Prov. Kalsel) \\
5 & April & $36.047 .467,49$ & 271.331 Milyar (Prov Kalsel) & 3.462 Milyar (Prov Kalsel) \\
\hline
\end{tabular}

Sumber: Dinas Pertambangan dan Energi Provinsi Kalimantan Selatan, 2015 
f) Penerimaan negara bukan pajak dari sektor minerba akan turun yang berdampak terhadap dana bagi hasil untuk kabupaten/kota, yang selama ini dikumpulkan kabupaten/kota.

g) PETI akan marak lagi, karena kabupaten/ kota tidak memiliki kewenangan, sementara provinsi tidak mungkin segera bisa melakukan pengawasan dan penindakan.

h) Para pegawai di kabupaten/kota banyak menganggur (karena semakin sedikitnya tugas dan fungsi yang bisa dikerjakan), sehingga pola pembinaan karier pegawai terganggu.

i) Kabupaten/kota akan kehilangan pegawai yang berkualitas (pengawas inspeksi tambang ditarik ke provinsi), sehingga menimbulkan keresahan bagi para pejabat dinas pertambangan dan energi di seluruh Kabupaten/Kota.

\section{Provinsi Kepulauan Bangka Belitung}

\section{Kondisi Pertambangan Mineral dan Batubara}

Potensi pertambangan dipengaruhi oleh banyak tanah yang mengandung mineral logam, antara lain bijih timah, besi, timbal, seng, bauksit, monasit, dan bahan galian bukan logam yang tersebar merata di wilayah tersebut, yaitu pasir kuarsa, kaolin, clay, pasir bangunan, kaolin, batu gunung, tanah liat dan granit. Potensi bahan galian logam terdiri atas besi primer, titan plaser, seng, timah, timbal, perak, monasit, xenotim. Usaha pertambangan didominasi oleh bahan galian timah sebanyak 671 buah $(73,7 \%)$, disusul oleh pasir kuarsa 53 buah (5,8\%), kaolin 45 buah $(4,94 \%)$, dan hematit 37 buah $(4,1 \%)$. Pengusahaan bahan galian lainnya rata-rata di bawah 3,0\% (Tabel 5).

Survei di Provinsi Kepulauan Bangka Belitung difokuskan di Kabupaten Belitung dan Belitung Timur. Kabupaten Belitung memiliki potensi pertambangan mineral bijih timah dan bahan galian yang tersebar secara merata, yaitu pasir kuarsa, pasir bangunan, kaolin, batu gunung, tanah liat dan granit. Sementara itu, Kabupaten Belitung Timur memiliki potensi bahan galian tambang: timah, pasir kuarsa, kaolin, granit, batu gunung, tanah liat dan bijih besi. Jumlah pemegang IUP seluruhnya 114 buah, yang terdiri atas IUP bahan galian logam 50 buah (batu besi 14 buah dan timah 36 buah), bukan logam 36 buah (pasir kuarsa 36 buah), dan batuan 28 buah (batu gunung 1 buah, kaolin 5 buah, pasir bangunan 15 buah, dan tanah liat 7 buah).
Tabel 5. Jumlah IUP di Provinsi Kepulauan Bangka Belitung, 2015

\begin{tabular}{llc}
\hline No. & \multicolumn{1}{c}{ Bahan Tambang } & Jumlah IUP \\
\hline 1 & Batu Granit & 7 \\
2 & Bauksit & 6 \\
3 & Besi & 1 \\
4 & Bijih Timah & 12 \\
5 & Galena & 1 \\
6 & Granit & 3 \\
7 & Hematit & 37 \\
8 & Ilmenit & 1 \\
9 & Kaolin & 45 \\
10 & Pasir Bangunan & 25 \\
11 & Pasir Kuarsa & 53 \\
12 & Pasir Laut+Timah & 12 \\
13 & Tanah Liat & 21 \\
14 & Tanah Urug & 2 \\
15 & Timah & 671 \\
16 & Timah Putih & 7 \\
17 & Wolfram + Wolframit & 2 \\
18 & Zirkon & 4 \\
\hline & Jumlah & 910 \\
\hline
\end{tabular}

Sumber: Dinas Pertambangan dan Energi Provinsi Kepulauan Bangka Belitung, data diolah kembali, 2015

\section{Pengelolaan Pertambangan Pasca Pemberlakuan UU 23/2014}

Survei di Provinsi Kepulauan Bangka Belitung dilakukan ke Dinas Pertambangan dan Energi kabupaten/kota, dengan mengambil sampel Kabupaten Belitung dan Kabupaten Belitung Timur. Kondisi pengelolaan pertambangan di dua kabupaten ini pasca pemberlakukan UU 23/2014 terdapat kesamaan, adanya pelimpahan kewenangan dari kabupaten/kota ke provinsi praktis secara umum sudah tidak ada aktivitas secara tugas dan fungsi, baik dari kegiatan perencanaan sampai dengan kegiatan pengawasan. Namun untuk kegiatan pengawasan, pihak Dinas Pertambangan dan Energi pada kedua kabupaten ini masih secara sporadis melakukan pengawasan setiap ada pengaduan dari masyarakat, di samping setiap pengaduan masyarakat atau pengusaha tambang selalu disampaikan ke tingkat provinsi. Dalam hal anggaran yang telah ada sesuai pengajuan untuk tahun anggaran 2015 pada dinas 
pertambangan di kedua kabupaten tersebut tetap tidak digunakan, dengan alasan karena secara tugas dan fungsi tidak bisa dijalankan, karena kewenangan pertambangan di kabupaten/kota telah dicabut sesuai UU 23/2014.

\section{PEMBAHASAN}

Penyerahan Urusan Pemerintahan dari Pemerintah Kabupaten/Kota ke Pemerintah Provinsi

Sesuai UU 23/2014, urusan konkuren terdiri atas:

1) Wajib terkait pelayanan dasar: urusan pemerintahan wajib yang sebagian substansinya merupakan pelayanan dasar.

2) Wajib tidak terkait pelayanan dasar: urusan pemerintahan wajib yang substansinya tidak mengandung pelayanan dasar, dan

3) Pilihan: urusan pemerintahan yang wajib diselenggarakan oleh daerah sesuai dengan potensi yang dimiliki daerah.

Dengan diberlakukannya UU 23/2014, setidaknya terdapat 49 urusan yang sebelumnya merupakan urusan pemerintah kabupaten akan menjadi urusan pemerintah provinsi (Gambar 3).
Beberapa implikasi diberlakukannya UU 23/2014 yang perlu dipersiapkan adalah:

a) Dalam hal pembiayaan, setidaknya terdapat sejumlah anggaran yang perlu disiapkan oleh provinsi yang dapat mencukupi berbagai kegiatan, baik pembiayaan untuk belanja kegiatan maupun pembiayaan untuk personil, belanja operasional dan belanja pemeliharaan yang dulu menjadi kewenangan kabupaten/kota, dalam hal ini 49 urusan yang dialihkan.

b) Dalam hal sarana dan prasarana, terdapat asetaset, baik aset yang bergerak dan aset yang tidak bergerak, yang akan diserahkan dalam rangka penyelenggaraan urusan yang akan dialihkan ke provinsi, antara lain: tanah, bangunan, kendaraan, komputer, perlengkapan/ peralatan kantor, dan peralatan kelitbangan.

C) Dalam hal personalia, terdapat sejumlah pegawai (PNS) yang terlibat langsung dalam penyelenggaraan 49 urusan yang diserahkan ke provinsi, belum termasuk pejabat struktural dan tenaga honorer yang masuk dalam struktur organisasi SKPD penyelenggaraan urusan, serta tenaga fungsional.

d) Dalam hal penyerahan dokumen, bahwa dalam penyelenggaraan urusan yang akan

\section{KONKUREN}

PEMERINTAHAN UMUM

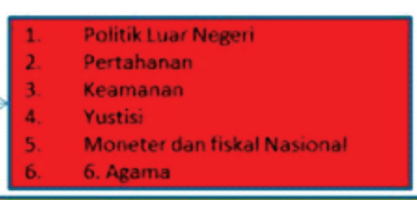

URUSAN WAIIB

\begin{tabular}{|c|c|}
\hline $\begin{array}{l}\text { Bersifat Pelayanan Dasar: } \\
\text { 1. Pendidikan } \\
\text { 2. Kesehatan } \\
\text { 3. Pekerjaan umum dan } \\
\text { penataan ruang } \\
\text { 4. Perumahan rakyat dan } \\
\text { kawasan permukiman } \\
\text { 5. Ketentraman, ketertiban } \\
\text { 6. umum \& linmas } \\
\text { sosial }\end{array}$ & 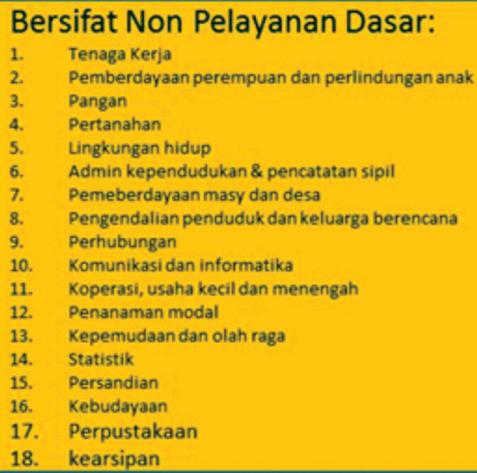 \\
\hline
\end{tabular}

URUSAN PILIHAN

1. Kelautan dan perikanan 2. pariwisata 3. pertanian 4. kehutanan 5. energi dan sumberdaya mineral 6. perdagangan 7. perindustrian 8. transmigrasi

Gambar 3. Skema pembagian urusan menurut UU.23/2014 
dialihkan ke pemerintah provinsi harus disertai penyerahan dokumen-dokumen prinsip, baik yang terkait substansi urusan secara langsung (seperti buku register perizinan, dokumen perizinan yang masih berlaku, dokumen personalia dan anggaran, dan lainnya). Berdasarkan analisis terdapat 33 jenis dokumen prinsip yang perlu diserahkan ke pemerintah provinsi.

Untuk itu dalam proses peralihan urusan dari kabupaten/kota ke provinsi diperlukan:

a) Persiapan dan perencanaan yang matang serta memerlukan koordinasi yang intensif antar pemerintah kabupaten/kota dengan pemerintah provinsi sehingga batas akhir penyelesaian pengalihan P3D dapat terlaksana sebelum tanggal 2 Oktober 2016 (batas akhir sesuai UU 23/2014).

b) Diperlukan pembentukan kelompok kerja (pokja)/tim khusus yang difasilitasi oleh pemerintah provinsi untuk menyusun petunjuk teknis sekaligus menyusun jadwal/tahapan proses pengalihan ke provinsi dengan melibatkan seluruh pemerintah kabupaten/kota dengan unsur-unsur wajib yang harus disertakan dalam pokja/tim tersebut adalah: bidang pemerintahan, bidang organisasi/kelembagaan, bidang SDM/kepegawaian, bidang keuangan, bidang hukum, bidang perencanaan, unsur pengawas intern (inspektorat), dan unsur SKPD terkait.

c) Mengingat terdapat juga urusan provinsi yang diserahkan kepada kabupaten, maka diminta kepada pihak pemerintah provinsi (antara lain; urusan penyiapan kebutuhan metrologi berupa tera, tera ulang dan pengawasan, yang penganggarannya telah melalui APBD Provinsi) untuk dapat mempersiapkan penyerahan Dokumen P3D Pemerintah Kabupaten Belitung Timur.

\section{Pengembangan Pertambangan Mineral dan Batu- bara Masa Transisi}

Pada naskah akademik rancangan undang-undang (RUU) pemerintahan daerah, menyebutkan bahwa tujuan RUU tersebut adalah untuk memperbaiki berbagai kelemahan dari UU 32/2004 (Kementerian Dalam Negeri, 2011). Beberapa kelemahan yang dimaksud adalah konsep kebijakan desentralisasi dalam negara kesatuan, hubungan antara pemerintah daerah dengan masyarakat sipil dan berbagai aspek penyelenggaraan pemerintahan daerah yang belum diatur.

\section{Pelayanan Dasar}

Pada Pasal 12 undang-undang ini membagi urusan pemerintahan yang berkaitan dan tidak berkaitan dengan pelayanan dasar. Urusan wajib pemerintah yang dikategorikan pelayanan dasar adalah pendidikan, kesehatan, pekerjaan umum dan penataan ruang, perumahan rakyat dan kawasan permukiman, ketenteraman/ketertiban umum dan perlindungan masyarakat, serta sosial. Sementara urusan pemerintahan wajib tetapi tidak masuk kategori pelayanan dasar menurut undang-undang ini adalah tenaga kerja, pemberdayaan perempuan dan perlindungan anak, pangan, pertanahan, lingkungan hidup, administrasi kependudukan dan pencatatan sipil, pemberdayaan masyarakat dan desa, pengendalian penduduk dan keluarga berencana, perhubungan, komunikasi dan informatika, koperasi dan usaha kecil-menengah, penanaman modal, kepemudaan dan olahraga, statistik, persandian, kebudayaan, perpustakaan dan kearsipan.

Kategori lainnya, selain urusan pemerintahan wajib, adalah urusan pemerintahan pilihan. Beberapa urusan yang dianggap urusan pemerintahan pilihan dan sudah pasti dianggap oleh penggagas undangundang ini tidak berkaitan dengan pelayanan dasar adalah kelautan dan perikanan, pariwisata, pertanian, kehutanan, energi dan sumber daya mineral, perdagangan, perindustrian, dan transmigrasi. Pembagian urusan pemerintahan wajib dan pilihan sebagai urusan pemerintahan konkuren yang menjadi kewenangan daerah masih perlu diperdebatkan karena terkait dengan pelayanan publik yang menjadi kebutuhan dasar masyarakat. Beberapa urusan pilihan di dalam undang-undang ini sebenarnya terkait erat dengan kebutuhan dasar masyarakat dalam membuka akses usaha bagi kalangan dunia usaha. Apalagi pemerintah telah menggelorakan gerakan kewirausahaan nasional sehingga urusan-urusan pilihan dalam undang-undang ini sebenarnya adalah urusan wajib pemerintah daerah untuk membantu masyarakat meningkatkan kesejahteraannya melalui jalur wiraswasta dalam berbagai bidang.

\section{Norma dalam Masa Transisi}

Menurut Dirjen Otonomi Daerah Kementerian Dalam Negeri, beberapa hal yang perlu dipedomani dalam masa transisi adalah:

a) Suburusan yang bersifat pelayanan kepada masyarakat luas dan masif, maka pemerintah kabupaten masih bisa melaksanakan urusan tersebut sampai 2 Oktober 2016. 
b) Masih banyak Suburusan Energi, Sumber Daya Mineral dan Batubara urusan bersifat pelayanan kepada masyarakat luas dan masif tidak tercantum dalam Surat Edaran Menteri Dalam Negeri Nomor 120/253/sj tanggal 16 Januari 2015.

c) Dirjen Otonomi Daerah beralasan kenapa suburusan bidang Energi, Sumber Daya Mineral dan Batubara bersifat pelayanan kepada masyarakat dan masif tidak tercantum dalam Surat Edaran Menteri Dalam Negeri, karena pihak Dirjen Mineral dan Batubara tidak menyampaikan usulan ke Menteri Dalam Negeri.

Menurut Dirjen Anggaran Kementerian Dalam Negeri, beberapa hal terkait anggaran yang perlu dipedomani dalam masa transisi adalah:

a) Apakah yang sudah teranggarkan dalam APBD terutama Dokumen Pelaksana Anggaran (DPA) Dinas Pertambangan dan Energi Kabupaten Banjar yang telah mendapatkan pengesahan masih bisa dilaksanakan untuk tahun 2015 secara penuh.

b) Pasal 18 PP No. 58/2005, menyebutkan bahwa Pengeluaran Daerah harus didukung dengan dasar hukum yang melandasi. Pasal 27 PP No.58/2005 APBD harus didasarkan pada urusan, organisasi, program dan kegiatan. APBD merupakan dasar belanja daerah. Penganggaran APBD Tahun 2015 didasarkan pada Permendagri No.37/2014, di mana proses perencanaan dan penganggaran sudah dimulai tahun 2014 sebelum UU 23/2014 ditetapkan.

C) Untuk program dan kegiatan yang ada dalam APBD Tahun 2015 yang sifatnya terkait langsung dengan masyarakat tetap dapat dilaksanakan, karena pemerintahan tidak bisa berhenti.

\section{Revisi UU 4/2009 dan Produk Hukum Turunannya}

Pemberlakuan UU 23/2014 terkait aspek kewenangan seperti yang tertera dalam Pasal 14 dan Pasal 15 secara perundang-undangan agar terjadi ketertiban dan kepastian hukum menuntut adanya revisi perbaikan terhadap UU 4/2009 dan produk hukum turunannya. Bahwa sesuai UU 4/2009, ditekankan tentang penguasaan negara atas mineral dan batubara, seperti dalam pengaturan perizinan, produksi, dan lainnya (Nalle, 2012), yang ditunjukkan perubahan Kontrak Karya (KK) menjadi IUP, yaitu negara memiliki hak mengatur, posisinya tidak sejajar lagi korporat (Mezak, 2011). Dalam UU 23/2014, penyelenggaraan urusan pemerintahan bidang kehutanan, kelautan, serta energi dan sumber daya mineral dibagi antara pemerintah pusat dan daerah provinsi (Pasal 14 ayat 1). Pembagian urusan pemerintahan konkuren antara pemerintah pusat dan daerah provinsi serta daerah kabupaten/kota tercantum dalam lampiran yang merupakan bagian yang tidak terpisahkan dari undang-undang ini (Pasal 15 ayat 1). Implikasi UU 23/2014 terhadap UU 4/2009 dapat divisualisasikan dalam Gambar 4.

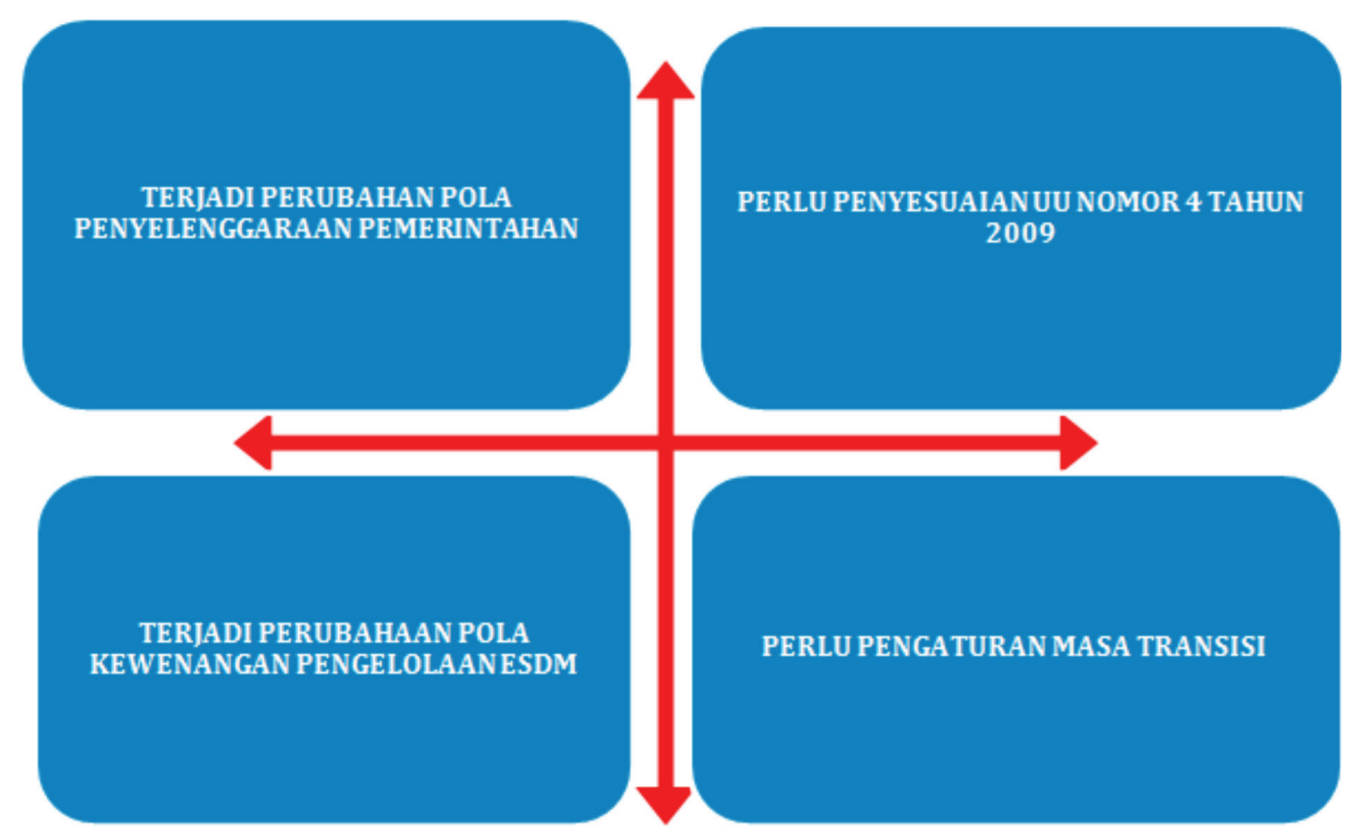

Gambar 4. Implikasi UU 23/2014 terhadap UU 4/2009 
Dalam rangka menjamin kepastian hukum dan sambil menunggu terbitnya peraturan pelaksanaan UU 23/2014, maka pada masa transisi ini pemerintah cq Kementerian ESDM telah mengeluarkan Surat Edaran Kementerian ESDM untuk dijadikan pedoman dalam pengelolaan pertambangan mineral dan batubara di daerah. Selain itu, Kementerian ESDM melakukan beberapa hal, antara lain:

a) Sejak berlakunya UU 23/2014, pengelolaan Inspektur Tambang (IT) dan Pejabat Pengawas menjadi kewenangan pemerintah pusat.

b) Meminta kepada Kadis ESDM provinsi/kabupaten/kota melakukan pendataan IT pada masing-masing SKPD.

c) Kementerian ESDM melakukan jejak minat bagi pejabat fungsional IT dan calon IT di provinsi dan kabupaten/kota yang berminat untuk mutasi menjadi Aparatur Sipil Negara di Kementerian ESDM yang ditempatkan di daerah.

d) Kementerian ESDM melakukan penyiapan revisi perubahan UU 4/2009 dan produk hukum turunannya berpedoman kepada UU 23/2014.

Berdasarkan proses persiapan revisi UU 4/2009 dan produk hukum turunannya telah diinventarisasi beberapa pasal yang segera harus disesuaikan. Selain penyesuaian beberapa pasal UU 4/2009 dengan UU 23/2014, dalam perbaikan tersebut juga menambahkan beberapa hal yang dipandang perlu untuk dimasukkan dalam revisi UU 4/2009 dan produk hukum turunannya (Heriyanto, 2015).

\section{KESIMPULAN DAN SARAN}

\section{Kesimpulan}

Dari hasil survei yang dilakukan terhadap empat provinsi, yaitu Jawa Barat; Jawa Timur, Kalimantan Selatan, dan Kepulauan Bangka-Belitung disimpulkan bahwa:

Reaksi yang ditimbulkan atas pemberlakuan UU 23/2014 hampir sama di setiap provinsi dan kabupaten yang disurvei. Mereka merasa kehadiran Undang-undang tersebut tanpa disosialisasikan secara utuh terlebih dulu dan dipaksakan, karena dikeluarkan menjelang berakhirnya pemerintahan Presiden Susilo Bambang Yudoyono. Kondisi ini pada akhirnya telah menimbulkan "kegaduhan" di setiap daerah, karena mereka, baik pemerintahan provinsi maupun pemerintahan kabupaten/kota, merasa belum siap menerima perubahan yang cukup fundamental.
Meskipun telah dikeluarkan Surat Edaran dari Menteri Energi dan Sumber Daya Mineral dan Menteri Dalam Negeri, yang juga diikuti oleh masing-masing gubernur, ketiadaan PP sebagai penjabaran dari UU 23/2014 menjadi kendala utama bagi kabupaten/ kota dalam melaksanakan ketentuan sebagaimana tercantum dalam undang-undang tersebut. Hal ini disebabkan Surat Edaran tersebut kurang implementatif serta kurang memiliki kekuatan hukum, sehingga dalam kenyataannya ada kabupaten/kota yang terpaksa mengeluarkan kebijakan sendiri untuk menghindari keadaan yang lebih buruk.

Telah terjadi "kebijaksanaan", baik disengaja maupun tidak disengaja, terhadap berbagai hal yang terkait dengan masalah perizinan. Sebagai contoh, pengusaha kecil yang menambang mineral tertentu dengan luas yang hanya ratusan meter persegi, kesulitan mengurus izin ke provinsi, karena menghabiskan waktu, tenaga, dan dana. Untuk itu, pemerintah kabupaten/kota mengambil "kebijaksanaan" yang memberi izin kepada pengusaha kecil tersebut tetap melaksanakan penambangan sambil menunggu proses perizinan selesai. Walaupun dianggap keliru dan cukup berisiko, langkah ini terpaksa diambil oleh pemerintah kabupaten/kota agar tidak terjadi hal-hal yang diinginkan.

Ada sikap skeptis yang tidak hanya ditunjukkan oleh pemerintah kabupaten/kota, tetapi bahkan juga oleh pemerintah provinsi, bahwa pemberlakuan UU 23/2014 tidak akan me-nemui sasaran sebagaimana yang diinginkan. Terlepas dari latar belakang alasan kedua pemerintahan di daerah tersebut, baik kabupaten/kota maupun provinsi, persoalan utamanya terletak kepada kekurangsiapan mereka me-nerima substansi UU 23/2014 yang dianggap kurang menggambarkan kondisi yang ada di lapangan.

\section{Saran}

Berdasarkan hasil studi kasus pengelolaan pertambangan mineral dan batubara pada 4 provinsi sebagai sampel, terjadinya persoalan carut-marut pengelolaan pertambangan mi-neral dan batubara, maka diperlukan revisi terhadap berbagai materi yang tercantum dalam UU 23/2014, atau, paling tidak, ditangguhkan pelaksanaannya sambil menunggu PP sebagai pelaksanaan dari undangundang tersebut.

Untuk memberi jaminan kepastian hukum dalam berusaha di bidang pertambangan mineral dan batubara, maka perlu segera melakukan revisi perbaikan UU 4/2009 dan produk hukum turunannya. 


\section{UCAPAN TERIMA KASIH}

Ucapan terima kasih saya sampaikan kepada Sdr. Ir. Darsa Permana dan Daldiri, peneliti dan ahli basis data pertambangan pada Puslitbang tekMIRA, yang telah bersedia diajak diskusi dan memberikan sebagian data, sehingga karya ilmiah ini dapat tersusun.

\section{DAFTAR PUSTAKA}

Ali, F. dan Kalla, 2011. Tepat redam tuntutan reposisi, dalam: Jazim Hamidi (ed), Optik Hukum Bermasalah: Peraturan Daerah Bermasalah, Jakarta, hal. 127-128.

Anderson J. E. (1994). Public policymaking. An Introduction. Boston, Toronto: Houghton Mifflin Company, $322 \mathrm{p}$.

Amrullah, F., 2010. Kebijakan umum dalam politik perundang-undangan di Indonesia, Jurnal Hukum, vol. VIII, no. 2, hal. 355-362.

Dinas Pertambangan dan Energi Provinsi Jawa Barat, 2015. Rekapitulasi Izin Usaha Pertambangan (IUP) di Provinsi Jawa Barat, data diolah kembali, 8 hal.

Dinas Pertambangan dan Energi Provinsi Kepulauan Bangka Belitung, 2015. Data Izin Usaha Pertambangan (IUP) di Provinsi Kepulauan Bangka Belitung, data diolah kembali, 4 hal.

Dinas Pertambangan dan Energi Provinsi Kalimantan Selatan, 2015. Rekapitulasi Izin Usaha Pertambangan (IUP) per Kabupaten di Provinsi Kalimantan Selatan Tahun 2015, Banjarbaru, data diolah kembali, 11 hal.

Dinas Pertambangan dan Energi Provinsi Kalimantan Selatan, 2015. Data Kontrak Karya (KK) dan Perjanjian Karya Pengusahaan Pertambangan Batubara (PKP2B) di Provinsi Kalimantan Selatan Tahun 2015, data diolah kembali, 6 hal.

Dinas Pertambangan dan Energi Provinsi Kalimantan Selatan, 2015. Produksi, royalti dan landrent batubara di Provinsi Kalimantan Selatan, 2011-2015.

Djohan, D., 2015. Kado Hari Otonomi, Kompas, 25 April 2015, http://www.rumahpemilu.org/in/read/8788/ Kado-Hari-Otonomi-oleh-Djohermansyah-Djohan

Heriyanto, 2015. Sinkronisasi dan konsultasi publik peraturan di bidang pertambangan mineral dan batubara, Bagian Hukum Sekretariat Direktorat Jenderal Mineral dan Batubara, Direktorat Jenderal Mineral dan Batubara, Kementerian Energi dan Sumber Daya Mineral, Bahan sosialisasi di Yogyakarta, 12 Oktober 2015, 18 hal.
Kementerian Dalam Negeri, 2011. Naskah Akademik RUU tentang Pemerintahan Daerah, Jakarta, 25 hal.

Malik, A.G. 2014. Menata Indonesia dari daerah. Laporan Eksekutif Indonesia Governance Index 2014, 34 Kabupaten/Kota di Indonesia, Jakarta, hal. 13.

Manan, B. dan Magnar, K., 1997. Beberapa masalah hukum tata negara Indonesia, Alumni, Bandung, hal. 286.

Marjuki, M., 2013. Kebijakan dalam filsafat, analisis manfaat filsafat terhadap masa depan manusia, dalam http://marjuki0.blogspot.co.id/2013/12/ kebijaksanaan.html. hal. 2-3.

Meha, N., 2010. Studi penelitian kebijakan, dalam http:// mehas3paudunj2010.blogspot.co.id/2011/01/studipenelitian-kebijakan.html,hal.1-7.

Mezak, M. H, 2011. Pengaturan hak penguasaan negara atas pertambangan studi perbandingan konsepsi kontrak karya dengan izin usaha pertambangan, Law Review vol. XI, no. 1, hal. 21-36.

Mulyatiningsih, E., 2011. Metode penelitian evaluasi kebijakan pendidikan, dalam http://staff.uny. ac.id/sites/default/files/pengabdian/dra-endangmulyatiningsih-mpd/4cmetode-penelitian-evaluasikebijakan-pendidikan.pdf.

Muslimin, B. dan Putra, M.,B., 2015. Menafsir UndangUndang Pemerintahan Daerah yang terbaru, Harian SINDO, Kamis, 8 Januari 2015.

Nalle, V.I.W., 2012. Hak menguasai negara atas mineral dan batubara pasca berlakunya Undang-Undang Minerba, Jurnal Konstitusi, vol. 9, no. 3, hal. 473494.

Peters, G. B, 2011. Governance as political theory, Critical Political Studies,vol.5 no.1, p. 63-72.

Priyanto, A., 2001. Tarik ulur pengelolaan pertambangan di era otonomi daerah, dalam Hukum Online.com http://www.hukumonline.com/berita/baca/hol4351/ tarik-ulur-pengelolaan-pertambangan-di-era-otonomi-daerah, Rabu, 05 Desember 2001.

Rahayu, S., 2011. Penelitian deskriptif-penelitian kebijakan, dalam http://pelawiselatan.blogspot.co.id/2011/01/ penelitian-deskriptif-penelitian.html, hal. 2-3.

Sahlan, M., 2011. Mendagri temukan 369 perda bermasalah 2011, Berita Kementerian Dalam Negeri, 2011 Selasa, 18 Januari 2011 19:39:51, http://www. kemendagri.go.id/news/2011/01/18/mendagritemukan-369-perda-bermasalah. 
Siswoyo, A., 2014. Dasar hukum otonomi daerah di Indonesia dari waktu ke waktu, dalam Blok Agus Siswoyo, 1 Desember, 2014, http://agussiswoyo. $\mathrm{com} /$ kewarganegaraan/dasar-hukum-otonomidaerah-di-indonesia-dari-waktu-ke-waktu/.

Sitorus, L.E., 2009. Release and discharge sebagai alternatif penyelesaian masalah (Studi Kasus Kebijakan Penyelesaian BLBI), hal. 41-46.

Undang-Undang Dasar Negara Republik Indonesia Tahun 1945.

Undang-Undang Republik Indonesia Nomor 4 Tahun 2009 tentang Pertambangan Mineral dan Batubara.
Undang-Undang Republik Indonesia Nomor 23 tahun 2014 tentang Pemerintahan Daerah.

Yarni, M., 2014. Penyusunan naskah akademik sesuai ketentuan Undang-Undang Nomor 12 Tahun 2011 dalam proses pembentukan Peraturan Daerah, Jurnal Ilmu Hukum, hal.155-172.

Yendra, T.B., 2011. Kilasan perkembangan otonomi (pemerintahan) daerah di Indonesia, dalam blok Dunia Hukum dan Sistem Hukum, http://www. boyyendratamin.com/2011/09/kilasan-perkembangan-otonomi.html, 4 September, 2011. 